\title{
Allozyme variation in the troglobitic millipede Stygiochiropus communis (Diplopoda: Paradoxosomatidae) from arid tropical Cape Range, northwestern Australia: population structure and implications for the management of the region
}

\author{
W.F. Humphreys ${ }^{1}$ and M. Adams ${ }^{2}$ \\ ${ }^{1}$ Western Australian Museum, Francis Street, Perth, Western Australia 6000, Australia \\ ${ }^{2}$ South Australian Museum, North Terrace, Adelaide, South Australia 5000, Australia
}

\begin{abstract}
The millipede genus Stygiochiropus is endemic to Cape Range in the arid tropics of northwestern Australia. The genus is restricted to caves throughout the range and is highly troglomorphic. Millipedes collected from 36 caves were examined for genetic variation at up to 27 allozyme loci. The allozyme data reveal the existence of three genetic provinces within Stygiochiropus communis. Between provinces there is an average of $25 \%$ fixed differences, indicating that no short-term gene flow occurs between any of the three. The provinces are loosely concordant with the geomorphological structure of Cape Range, namely with the gorges which cut through the cavernous limestone into a non-cavernous limestone below. The three genetic provinces have different characteristics; the southern province is genetically much more homogeneous that the northern or central provinces. There are also a large number of statistically significant differences in allele frequency, involving $10 \mathrm{loci}$, between caves within each province, with the number increasing from south to north. The loci involved in any province differ entirely from those exhibiting differences in the other provinces. Within provinces, distant caves may exhibit no significant differences in allele frequency from one another whereas caves spatially much closer may show substantial allozymic differences. This result suggests that the genetic structuring within provinces is associated with surface drainage basins as well as with deep gorges within the provinces and indicates that the discrete sub-population model should be applied to the population structure in this species between and, in some cases, within genetic provinces. The general concordance of the major provinces with those found in other terrestrial and aquatic troglobitic taxa suggests that the overall management of the Cape Range karst should take cognisance of these genetic patterns. It suggests also that the northern part of the range, which is a more immature karst development, is likely to contain a diversity of distinct species across many taxa. The clear differentiation of the three genetic provinces, plus the northern area outside the range of $S$. communis where several additional species of Stygiochiropus occur, suggest that each area is likely to contain a suite of troglobitic species restricted to these areas. In addition, the absent or severely restricted gene flow between many caves within the karst provinces is likely to be reflected in other members of the rich troglobitic fauna of Cape Range. Comprehensive conservation of the troglobitic fauna requires that populations are maintained throughout the extent of Cape Range.
\end{abstract}

\section{INTRODUCTION}

The caves in Cape Range, north-western Australia (Figure 1), contain a rich troglobitic fauna obligate inhabitants of caves and other subterranean voids (Humphreys, 1993b, 2000). The region has long been arid, supporting a vegetation mainly of tussock grass and Acacia, and is separated by thousands of kilometres across the Great Sandy Desert from the nearest rainforest. Despite this the composition of the troglobitic fauna indicates that it is, in part, a relict rainforest litter fauna (Humph- reys, 1989, 1993a, 1993c; Harvey et al., 1993) having affinities with both tropical and temperate rainforest faunas. The community includes a wide variety of arthropod troglobites including insects, arachnids, crustacea and myriapods (Humphreys, 1993a, 1993b, 2000).

A dominant member of the troglobitic fauna is a genus of highly cave-adapted (troglomorphic) millipedes, Stygiochiropus Humphreys and Shear, 1993 (Diplopoda: Polydesmida: Paradoxosomatidae: Australiosomatinae: Antichiropodini), 
endemic to Cape Range. These millipedes are abundant in very humid caves and have been found in more than 63 caves of more than 500 caves identified (R.D. Brooks, personal communication, 1999), covering most of Cape Range (Humphreys and Shear, 1993; Shear and Humphreys, 1996).

Populations of one species, Stygiochiropus communis Humphreys and Shear, 1993, are found in the southern $70 \%$ of Cape Range and have a range of about $770 \mathrm{~km}^{2}$ (Humphreys and Shear, 1993) and are known from 61 caves. Stygiochiropus communis occurs in quite varied cave habitats (Humphreys, 1989, 1991a, 1991b) where it is occasionally abundant (Humphreys, 1991b; Humphreys and Shear, 1993) and easily located on the banks of cave soil; in addition the species is polymorphic at many allozyme loci (Humphreys, 1989, 1991b; Adams and Humphreys, 1993). Together these characteristics make $S$. communis an ideal target species for detailed population genetic study as a means of gaining insight into the nature of the cave systems in Cape Range. Such information is highly relevant to one of the central management issues for this region of extraordinary subterranean biodiversity (Humphreys, 2000): whether the karst region comprises a single subterranean community linked through cracks and conduits within the limestone (mesocavernous voids), or whether it consists of numerous isolated cave systems supporting separate communities.

Although other troglobitic groups occupy the cave systems of Cape Range, previous ecological and allozyme studies have indicated that none fulfil all of the above conditions as potential indicator species (Adams and Humphreys, 1993). Amongst the millipedes, for example, three other congeneric species, S. sympatricus Humphreys and Shear, 1993, S. isolatus Humphreys and Shear, 1993, and S. peculiaris Shear and Humphreys, 1996, are each known from only one location. Siphonophorid and polyxenid millipedes have been collected from caves and the endemic epigean paradoxosomatid millipedes, Antichiropus humphreysi Shear, 1992, and the monotypic Boreohesperus capensis Shear, 1992, are also known from the region. However, none of these species is abundant, widespread or sufficiently cavernicolous to provide any general overview of the caves of Cape Range.

Previous morphological and allozyme overviews have revealed that Stygiochiropus communis displays considerable genetic divergence without clear morphological separation (Adams and Humphreys, 1993; Humphreys and Shear, 1993). Much but not all of this genetic divergence was explained by the presence of southern, central, and northern genetic provinces, each isolated from one another by geomorphological features. However, neither study probed the population genetic structure within these three genetic provinces in any detail, nor did they address the key issue of gene flow. These latter two issues are dealt with in this paper using many populations, a step considered crucial by Caccone (1985).

Of the various strategies now available to estimate gene flow from genetic markers, none is clearly superior to the standard approach based on Wright's model and allozyme markers (Neigel, 1997), particularly in any initial overview of a comparatively rare organism. This study uses allozyme analysis to examine the population structure of $S$. communis in Cape Range sensu stricto. Our aims are to derive a suitable management overview of the Cape Range karst, and through an examination of gene flow estimates to derive some understanding of its interconnections, given that dye-tracing (Alexander and Quinlan, 1992) is impractical in the caves, largely inactive, of this arid region.

\section{Background}

The regional, climatic and biological setting has been described (Humphreys, 1989, 1990, 1991a, 1991b, 1991c, 1991d; Humphreys and Adams, 1991; Humphreys et al., 1989; Humphreys and Collis, 1990; Humphreys and Shear, 1993) and only sufficient information is given here to aid understanding of the system.

Cape Range lies just within the semi-arid tropics of Western Australia (Figure 1), a region with episodic and highly unpredictable rainfall (Humphreys et al., 1989). This is important because the troglobitic fauna relies in part on organic matter and water entering the caves following heavy rain. Such intermittent flooding rejuvenates the cave fauna and permits the populations to occupy the caves more widely and to commence breeding (Humphreys et al., 1989; Humphreys, 1991d; Humphreys and Shear, 1993).

The interval between floods depends on the characteristics of the cave and its catchment, as well as the magnitude of rainfall events in the area. The drying rate of a cave depends on the water storage capacity of the cave sediments and the size of the entrance relative to cave volume. Some caves flood after $25 \mathrm{~mm}$ of rain and dry quickly, while others flood only after $>156 \mathrm{~mm}$ rain and dry slowly (Humphreys, 1989; Humphreys et al., 1989). Hence, wetting and drying cycles within caves may vary from a month to several years. In consequence, there are pulses in the population numbers within caves throughout Cape Range so that the populations expand into caves from the crevicular system and withdraw from the caves with varying frequency and amplitude (Figure 2), and not necessarily in synchrony. Hence, the caves in Cape Range have highly dynamic troglobite communities (Humphreys, 1991d) and belie the stability often attributed to such systems. 


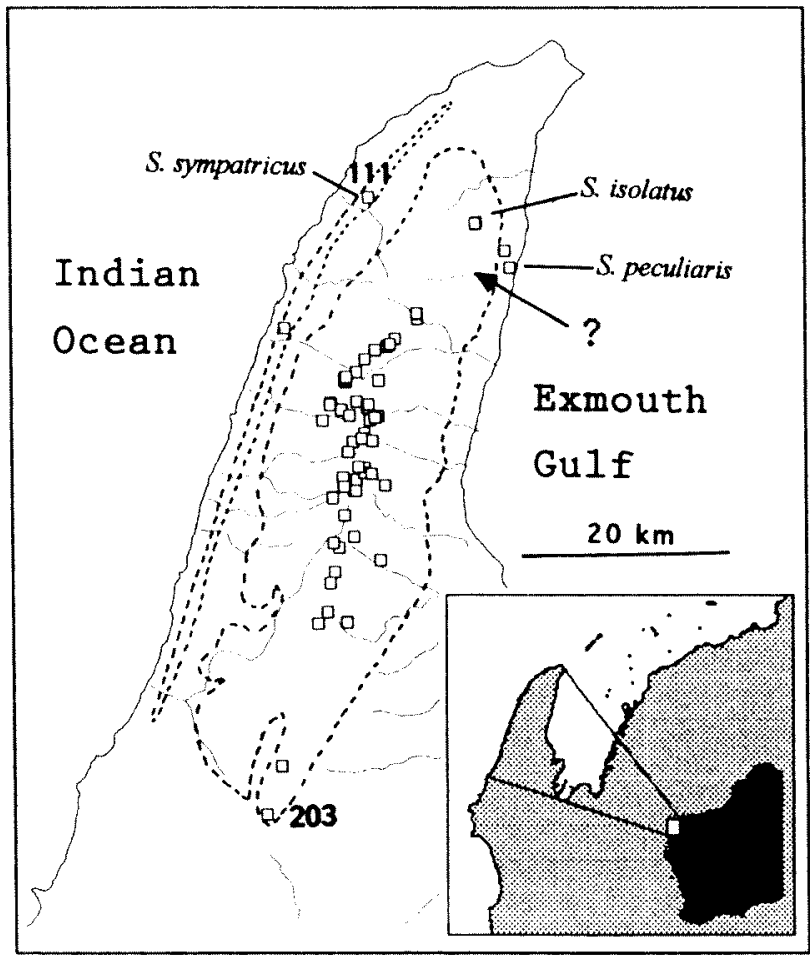

Figure 1 The location of Cape Range in Western Australia and of caves containing Stygiochiropus communis on the Cape Range peninsula. Cape Range encompasses all the outcropping Tulki Limestone (dashed lines) in which the caves containing troglobites are found. Stygiochiropus communis ranges from cave C-111, where it is sympatric with $S$. sympatricus, to $\mathrm{C}-203$, an outlying population in the far south. The unique locations of $S$. isolatus and $S$. peculiaris are shown. The question mark denotes a region with abundant Stygiochiropus of unknown affinity on a mining lease. The distribution of the exposures of marly non-cavernous Mandu Limestone in the deeper gorges is given in Humphreys (1993a: frontispiece), together with a satellite image of the range (ibid. front cover).

The wetting and drying cycles and the addition of energy (organic matter) to the caves are independent of the population events, while the reduction of organic carbon within the cave is coupled with the energy flow through the community of cave organisms (Humphreys, 1991b).

Caves housing populations of troglobitic animals have traditionally been of interest to evolutionary biologists owing to their stable climates, easily defined populations and simple community structure. However, it has become apparent that many, perhaps most cave populations represent only a small, often temporary colonisation event by a broader population widely dispersed through the interstices crevices, cracks and mesovoids generally permeating many karst regions (Howarth, 1983). Similarly the view of stable populations is dispelled in those areas where periodic rainfall results in large scale extirpation of populations within the cave itself followed by an increase in numbers from the crevicular system through immigration, and especially reproduction, enabled by the influx of food and water resources (e.g. Cape Range; Humphreys, 1991d). These events lead to a major change in cohort structure of the population, from a typical old age (V-shaped 'pyramid' of numbers) to a young population structure (inverted V-shaped: Humphreys, 1991b), a change that is presumably accompanied by altered selection pressures.

In Cape Range these population events are likely to involve bottlenecks, isolation and remixing of populations over a wide range of spatial and temporal scales. Such attributes may themselves be influential in the derivation of the large genetic diversity seen in $S$. communis (Adams and Humphreys, 1993). Besides the stochastic effects due to low numbers of founders, there are probably many traits for which the founders of a new population are likely to be a non-random sample of their original population (Olivieri et al., 1990). Similarly the process of extinction and recolonization sets up an age distribution at the level of populations (McCauley, 1991). As a cohort ages, allele frequencies can change under the influence of drift and migration (ibid.), while, under some circumstances, a population bottleneck can itself result in an increase in genetic variation in the population (Carson, 1990).

\section{Methods}

Millipedes were snap frozen in liquid nitrogen with replicate material preserved in alcohol. Homogenates were made from whole individuals and used to examine the allozyme variation within and between the populations in Cape Range. Cellulose acetate gel electrophoresis was conducted using the principles and methods of Richardson et al. (1986).

A pilot study was conducted on four specimens of $S$. communis from each of 10 caves broadly dispersed throughout Cape Range. This study having demonstrated the suitability of using allozyme data for assessing population structure in this species, a more comprehensive set of samples was collected two years later from 36 caves and examined for a subset of the loci used in the pilot study. All but one (C-203) of the 10 caves sampled in the pilot study were subsequently resampled for inclusion in the main allozyme screening.

The caves are referred to by the number allocated under the auspices of the Australian Speleological Federation in the Australian Karst Index (Matthews, 1985); the C- prefix identifies the cave number as belonging to the Cape Range Karst.

A total of 46 enzymes or non-enzymatic proteins 


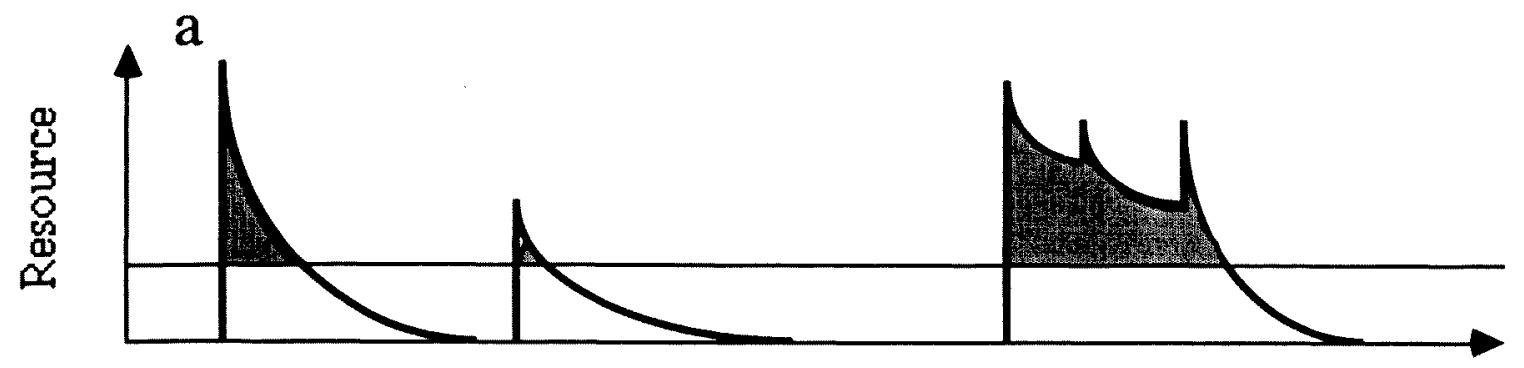

b

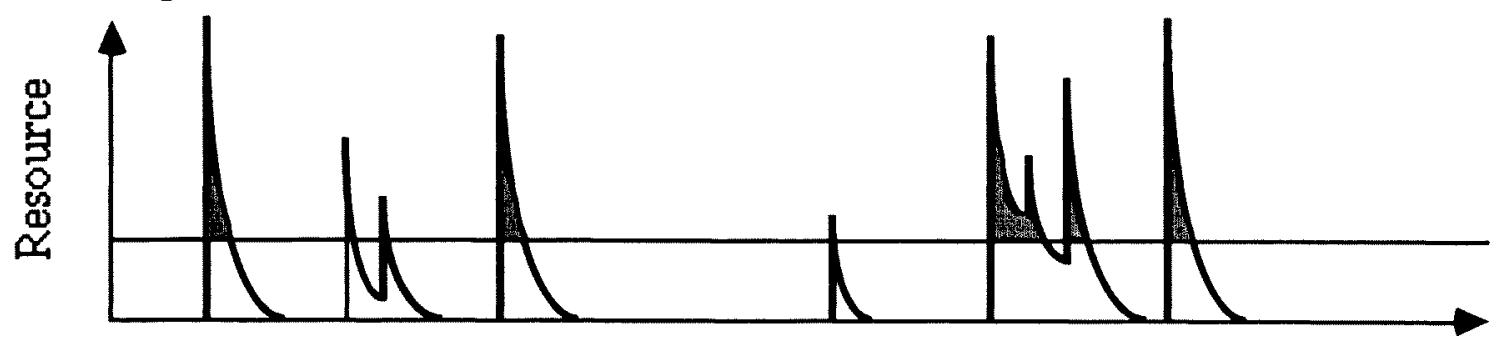

Time

Figure 2 Hypothetical model describing the availability and depletion of resources in the caves of Cape Range. a) Slow drying (small entrance) cave with a small catchment. b) Fast drying cave with a large catchment. The fine horizontal line denotes the resource level (energy or water) below which the populations are eliminated from the cave. Population responses would show a lag after the influx of new resources. Caves with a large catchments (b) flood and are recharged with energy more frequently. Slow drying caves (a) maintain populations (shaded) for longer after flooding (after Humphreys, 1991d).

were examined in the pilot study, of which the following 25 were considered scorable: aconitate hydratase (ACON, E.C. 4.2.1.3), adenosine deaminase (ADA, E.C. 3.5.4.4), alcohol dehydrogenase (ADH, E.C. 1.1.1.1), fructosebisphosphate aldolase (ALD, E.C. 4.1.2.13), alkaline phosphatase (AP, E.C. 3.1.3.1), diaphorase (DIA, E.C. 1.6.99.), enolase (ENOL, E.C. 4.2.1.11), fructosebisphosphatase (FDP, E.C. 3.1.3.11), fumarate hydratase (FUM, E.C. 4.2.1.2), aspartate aminotransferase (GOT, E.C. 2.6.1.1), general protein (GP), glucose-6-phosphate isomerase (GPI, E.C. 5.3.1.9), glutathione reductase (GSR, E.C. 1.6.4.2), hexokinase (HK, E.C. 2.7.1.1), isocitrate dehydrogenase (IDH, E.C. 1.1.1.42), cytosol amino peptidase (LAP, E.C. 3.4.11.1), L-lactate dehydrogenase (LDH, E.C. 1.1.1.27), malate dehydrogenase (MDH, E.C. 1.1.1.37), mannosephosphate isomerase (MPI, E.C. 5.3.1.8), dipeptidase (val-leu; PEPA, E.C. 3.4.13.), tripeptide aminopeptidase (leu-leu-leu; PEPB, E.C. 3.4.11), proline dipeptidase (phe-pro; PEPD, E.C. 3.4.13.), phosphoglycerate mutase (PGAM, E.C. 5.4.2.1), pyruvate kinase (PK, E.C. 2.7.1.40) and triosephosphate isomerase (TPI, E.C. 5.3.1.1). In addition the enzyme dipeptidase (lys-leu; PEPC, E.C. 3.4.13.) was used in the main screen but not the pilot study. The nomenclature for referring to loci and allozymes follows Adams et al. (1987).

Stygiochiropus communis meets the criteria for adequate genetic work at the within-species level
(Richardson et al., 1986) in that there were at least six polymorphic loci, the samples could be drawn from the smallest and most homogeneous population units (caves), and they were sampled over varying geographical distances including the extremities of their range and intermediate locations. For systematic purposes, the null hypothesis under test was that all populations were sampled from the gene pool of a single species. The sample sizes per cave (mostly $3+$; mean $=7.53$ ) are entirely adequate for initial systematic studies on allopatric populations (Richardson et al., 1986), and can also provide significant insight into population substructure where obvious heterogeneity in allele frequencies is apparent (Hudson and Adams, 1996).

\section{Data analysis}

The allozyme data were analysed using the computer programs GENEPOP Version 3.16 (Raymond and Rousset, 1995) and STATISTICA Release 5 (StatSoft Inc., 1997). The statistical significance of all p- values was interpreted after applying a sequential Bonferroni adjustment to correct for multiple tests (Hochberg, 1988).

Within-cave tests of Hardy-Weinberg equilibrium and linkage disequilibrium were conducted using GENEPOP to determine unbiased estimates of exact p-values using the Markov chain method. Pairwise comparisons of allele frequency between caves were also conducted.

Genetic distances were calculated either as 
percent fixed differences (\% FD; Richardson et al., 1986), Nei's genetic distance corrected for small sample sizes (Nei, 1978), or Rogers' genetic distance (Rogers, 1972). The genetic relationships amongst caves were also assessed by applying the multivariate technique of multidimensional scaling (MDS), part of STATISTICA, to a matrix of Rogers' genetic distance.

For the quantitative data, means were compared by analysis of variance followed up by Fisher's PLSD with $\alpha=0.05$.

\section{RESULTS AND DISCUSSION}

\section{Pilot Study}

A total of 27 presumptive loci were scored in the pilot study (Table 1). The allozyme data show no evidence that any of the cave populations departed from Hardy-Weinberg equilibrium (analyses not shown). Two major genetic groupings were evident, differing at an average of $19 \%$ of loci (Group I: C118, 126, 167 and 203; Group II: C-18, 64, 103, 106, 107 and 159). The four populations in Group I were genetically homogeneous. Within Group II the population from $\mathrm{C}-64$ differed from all others at 7 $15 \%$ FDs. Group I, Group II, and C-64 are each separated by one or more deep gorges (Figure 3) that have cut down through the cavernous Tulki Limestone into the underlying and marly noncavernous Mandu Limestone (Humphreys, 1991b, 1993a), and which may be expected to offer barriers to the lateral movement of obligate subterranean species. This general pattern of genetic structuring is also seen in Draculoides vinei (Harvey, 1988) (Arachnida: Schizomida: Hubbardiidae) and Norcapensis mandibulis Bradbury and Williams, 1997 (Amphipoda: Melitidae), other obligate subterranean inhabitants of the same area, but not in Laevophiloscia yalgoonensis Wahrberg, 1922 (Isopoda: Philosciidae), a sympatric epigean species (Adams and Humphreys, 1993).

Hence, the pilot study suggested that there is no gene flow between three readily identifiable karst sub-provinces. Indeed, the magnitude of the genetic distances between sub-provinces indicates the possibility of sibling species. We will hereafter refer to these three areas collectively as genetic

Table 1 Allozyme frequencies at 27 loci for the 10 caves selected for the pilot study. Frequencies were expressed as a percentage and shown as a superscript; where polymorphic, the frequency of the least common allele can be obtained by subtraction. The maximum sample size for each cave $=4$ (i.e. 8 haploid genomes). A dash indicates no individuals were scorable for this locus. Loci marked with an asterisk were not used in the main study either because they were invariant ( $A l d, A p, G p, G s r, I d h, P k)$ or were prone to display age related subbanding (Lap, Ldh, Mpi, Pgam). Three invariant loci (Enol, Got1, Mdh1) were used in the main study to increase the number of loci available to detect private alleles (Slatkin, 1985).

\begin{tabular}{|c|c|c|c|c|c|c|c|c|c|c|}
\hline Cave & C64 & C18 & C103 & C106 & C107 & C159 & C118 & C126 & C167 & C203 \\
\hline Acon & $\mathrm{d}$ & $c^{75} a$ & $c^{50} \mathrm{e}^{37} \mathrm{~d}$ & $\mathrm{c}$ & $c^{75} a^{13} b$ & $b^{88} c$ & $c$ & $c$ & $c$ & c \\
\hline Ada & $\mathrm{f}$ & f & f & $\mathrm{f}$ & $\mathrm{f}^{5} \mathrm{~g}$ & $\mathrm{f}$ & $d^{50} e$ & $e^{62} d$ & $e^{87} d$ & $\mathrm{~d}$ \\
\hline$A d h$ & $\mathrm{c}$ & $c$ & c & c & $c^{\circ}$ & $\mathrm{c}$ & $\mathrm{b}$ & $b$ & $b$ & $b^{88} c$ \\
\hline Ald ${ }^{*}$ & $\mathrm{a}$ & $\mathrm{a}$ & $\mathrm{a}$ & $\mathrm{a}$ & $\mathrm{a}$ & $\mathrm{a}$ & $\mathbf{a}$ & $a$ & a & $a$ \\
\hline$A p^{*}$ & $\mathrm{a}$ & $\mathrm{a}$ & $a$ & $a$ & $a$ & $a$ & $\mathrm{a}$ & $a$ & $a$ & a \\
\hline Dia & $\mathrm{b}$ & $b^{75} d$ & $b$ & $d^{62} b$ & $b^{50} d$ & $b$ & $b$ & $b$ & $b$ & $b$ \\
\hline Enol & $a$ & $a$ & $\mathrm{a}$ & $a$ & a & $a$ & $a$ & $\mathbf{a}$ & $a$ & $\mathbf{a}$ \\
\hline$F d p$ & $\mathrm{~b}$ & c & $\mathrm{c}$ & c & $c^{75} b$ & $c$ & $\mathrm{c}$ & c & c & c \\
\hline Fum & $b$ & $\mathrm{~b}$ & $b^{88} d$ & b & $\mathrm{b}$ & $b^{75} d$ & $\mathrm{~b}$ & $\mathrm{~b}$ & $b$ & $\mathrm{~b}$ \\
\hline Got1 & $\mathrm{a}$ & $\mathrm{a}$ & $a$ & $\mathrm{a}$ & a & $\mathrm{a}$ & $\mathrm{a}$ & $\mathrm{a}$ & a & $\mathrm{a}$ \\
\hline Got2 & $c$ & c & $a^{88} c$ & $\mathrm{c}$ & $c^{87} \mathrm{a}$ & $c^{62} a$ & $\mathrm{c}$ & c & c & $c$ \\
\hline$G p^{*}$ & $\mathrm{a}$ & $\mathrm{a}$ & $\mathbf{a}$ & $a$ & $a$ & a & a & $a$ & $\mathrm{a}$ & $\mathrm{a}$ \\
\hline Gpi & $d^{75} c$ & $b^{63} c$ & $\mathrm{~d}^{87} \mathrm{c}$ & $c^{63} e^{25 f}$ & $d^{50} c^{25} e$ & $c^{88} \mathrm{~d}$ & $\mathrm{C}$ & $c^{87} b$ & $c^{87} \mathrm{~b}$ & $c$ \\
\hline Gsr* & $\mathrm{a}$ & a & $a$ & $\mathrm{a}$ & $a$ & $a$ & a & $a$ & $\mathrm{a}$ & $a$ \\
\hline$H k$ & $c$ & $b$ & $b$ & $b$ & $b$ & - & c & C & $c$ & $c$ \\
\hline$I d h^{*}$ & $\mathrm{a}$ & a & $\mathrm{a}$ & $\mathrm{a}$ & $\mathrm{a}$ & $\mathrm{a}$ & $a$ & $\mathrm{a}$ & a & - \\
\hline $\operatorname{Lap}^{*}$ & $d^{75} \mathrm{c}$ & $c$ & $\mathrm{~d}^{75} \mathrm{c}^{13} \mathrm{e}$ & $d^{87} c$ & $d^{38} c^{25} a^{13} b^{12} e$ & $c^{50} d$ & c & $\mathrm{c}^{58} \mathrm{~d}$ & c & $c$ \\
\hline$L d h^{*}$ & $\mathrm{a}$ & $\mathrm{a}$ & a & a & $a^{88} b$ & $\mathrm{a}$ & $\mathrm{a}$ & $\mathrm{a}$ & a & a \\
\hline$M d h I$ & $\mathrm{~b}$ & $\mathrm{~b}$ & $b$ & $b$ & $b$ & $b$ & $b$ & $b$ & $b$ & $b$ \\
\hline$M d h 2$ & $c$ & $c^{75} a$ & C & c & c & $\mathrm{c}$ & $e$ & $\mathrm{e}$ & $\mathrm{e}$ & $e$ \\
\hline$M p i^{*}$ & $a^{63} b$ & $a^{50} b$ & $a$ & $b^{67} a$ & $b^{62} a$ & a & $\mathrm{a}$ & $a$ & $\mathrm{a}$ & a \\
\hline PepA & $\mathrm{b}$ & $\mathrm{b}$ & $b$ & b & $b$ & $b$ & $b$ & $b$ & $b^{75} a$ & $\mathrm{~b}$ \\
\hline PepB & $\mathrm{d}$ & $d^{63} \mathrm{f}$ & $d$ & $\mathrm{~d}$ & $\mathrm{~d}$ & $\mathrm{~d}$ & $\mathrm{~b}$ & $b$ & $\mathrm{~b}$ & $b$ \\
\hline PepD & $\mathrm{d}$ & $\mathrm{d}$ & $\mathrm{d}$ & $d$ & $\mathrm{~d}$ & $\mathrm{~d}$ & d & $\mathrm{d}$ & $\mathrm{d}$ & $\mathrm{d}$ \\
\hline Pgam* & $c^{28} \mathrm{~d}$ & $b^{75} a^{13} c$ & $b$ & b & $b^{63} a^{25} c$ & $\mathrm{~b}$ & $b^{63} \mathrm{e}$ & $b^{75} e$ & $\mathrm{~b}^{88} \mathrm{e}$ & $e^{75} b$ \\
\hline$P k^{*}$ & $a$ & $\mathrm{a}$ & $a$ & $\mathrm{a}$ & $a$ & $\mathrm{a}$ & $\mathrm{a}$ & $a$ & $\mathrm{a}$ & $\mathrm{a}$ \\
\hline$T p i$ & $b^{75} c$ & $b^{67} \mathrm{a}$ & $b$ & $b$ & $\mathrm{~b}$ & $b$ & $b$ & $b$ & $b$ & $b$ \\
\hline
\end{tabular}




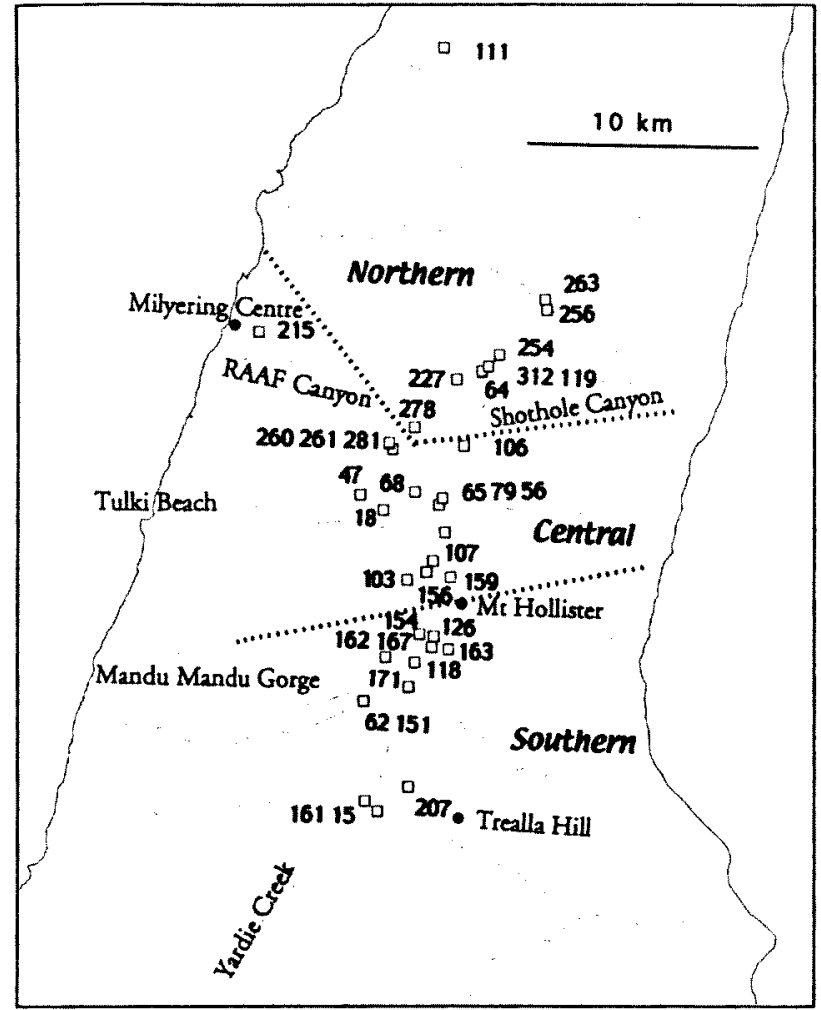

Figure 3 The locations of samples used for the allozyme study (open squares). The dotted lines across the range denote the boundaries between the three major genetic subregions (provinces) as indicated by the electrophoretic work. C-203 lies $26 \mathrm{~km}$ south south west of C15 (see Figure 1). Geographical locations are denoted by filled circles and the features mentioned in the text are named. provinces, and individually as the southern, central, and northern genetic provinces.

\section{Main Study}

As the pilot study revealed a sufficient number of polymorphic loci both overall and in most cases within each genetic province, it was clear that a more comprehensive survey of $S$. communis across its range would provide additional insight into population structure in the species. A further 271 millipedes were collected for the main study. These were obtained from 36 of the 53 caves then known to have harboured S. communis, thus providing a significant regional coverage of its distribution in Cape Range (Figure 3). Millipedes were genotyped at 18 loci; the allele frequencies for each cave population are presented in Tables 2 (southern province), 3 (central province), and 4 (northern province).

\section{Within-cave analyses}

An examination of the within-cave tests of HardyWeinberg equilibrium showed that none of the 36 individual populations displayed genotype frequencies inconsistent with Hardy-Weinberg equilibrium (all $\mathrm{P}$-values $>0.01$ and none significant after sequential Bonferroni correction). None of the 18 loci in a multi-population test displayed any evidence of deviation from Hardy-Weinberg equilibrium (lowest $\mathrm{P}$-value $>0.05$ after correction), giving a result across all loci and populations of $\mathrm{P}=$ $0.33 \pm 0.01$ standard error. Moreover, none of the nine caves previously sampled in the pilot study displayed any significant temporal differences in allele frequency over the two year period. Hence, these analyses show no evidence of population

Table 2 Allozyme frequencies at 18 loci for the 12 caves within the southern genetic province. Presentation of the frequencies as per Table 1 . The maximum number of haploid genotypes $(2 \mathrm{~N})$ for each cave is shown in brackets.

\begin{tabular}{|c|c|c|c|c|c|c|c|c|c|c|c|c|}
\hline $\begin{array}{l}\text { Cave } \\
\text { Locus }\end{array}$ & $\begin{array}{l}\text { C15 } \\
\text { (20) }\end{array}$ & $\begin{array}{l}\text { C62 } \\
\text { (2) }\end{array}$ & $\underset{\text { (2) }}{\mathrm{C} 118}$ & $\begin{array}{l}\mathrm{C} 126 \\
\text { (24) }\end{array}$ & $\begin{array}{c}\text { C151 } \\
\text { (4) }\end{array}$ & $\begin{array}{l}\text { C154 } \\
\text { (14) }\end{array}$ & $\begin{array}{l}\text { C161 } \\
\text { (18) }\end{array}$ & $\begin{array}{l}\text { C162 } \\
\text { (14) }\end{array}$ & $\begin{array}{l}\text { C163 } \\
\text { (20) }\end{array}$ & $\begin{array}{l}\text { C167 } \\
\text { (12) }\end{array}$ & $\begin{array}{l}\text { C171 } \\
\text { (18) }\end{array}$ & $\begin{array}{l}\text { C207 } \\
\text { (20) }\end{array}$ \\
\hline Acon & c & c & c & $c^{96} \mathbf{a}$ & $c^{75} b$ & c & c & $c^{85} b^{7} d$ & $c^{95} b$ & $c$ & $c^{88} d$ & $c$ \\
\hline Ada & $d^{75} e^{10} a^{5} b^{5} c$ & d & $\mathrm{d}^{50} \mathrm{e}$ & $\mathrm{e}^{54} \mathrm{~d}$ & $d^{75} e$ & $e^{90} d$ & $\mathrm{~d}$ & $e^{57} d$ & $\mathrm{e}^{70} \mathrm{~d}$ & $d^{50} \mathrm{e}$ & $d^{94} b$ & $\mathrm{~d}$ \\
\hline Adh & $\mathrm{b}$ & b & $\mathrm{b}$ & $\mathrm{b}$ & $\mathrm{b}$ & b & a & $\mathrm{b}$ & $\mathrm{b}$ & $\mathrm{b}$ & $b^{83} \mathrm{a}$ & b \\
\hline Dia & b & b & b & b & b & b & b & b & $b^{95} \mathrm{c}$ & $b^{92} c$ & $\mathrm{~b}$ & b \\
\hline Enol & a & a & - & a & a & a & a & a & a & a & a & $\mathbf{a}$ \\
\hline$F d p$ & c & c & c & c & c & c & c & c & c & c & c & c \\
\hline Fum & b & b & - & b & b & b & $\mathrm{b}$ & $\mathrm{b}$ & b & b & b & b \\
\hline Got1 & a & a & a & a & a & a & a & a & a & a & a & a \\
\hline Got2 & $c^{75} d$ & c & c & c & c & $c^{93} a$ & c & c & $c^{95} \mathrm{~d}$ & c & c & $c^{95} b$ \\
\hline Gpi & $c^{80} \mathrm{~d}$ & c & c & $c^{75} d^{17} b$ & c & $c^{86} \mathrm{~d}$ & c & $c^{71} d^{15} a^{7} b$ & $c^{75} d^{15} b$ & c & c & c \\
\hline$H k$ & c & c & c & c & c & $c^{7 \%} b$ & c & c & c & c & - & c \\
\hline$M d h 1$ & b & b & b & $\mathrm{b}$ & b & b & b & $\mathrm{b}$ & b & b & $b^{89} c$ & b \\
\hline$M d h 2$ & e & e & $\mathrm{e}$ & e & e & e & e & e & $\mathrm{e}$ & e & $\mathrm{e}$ & e \\
\hline PepA & $b^{95} \mathrm{c}$ & b & b & $b^{92} a$ & b & b & b & $b^{79} a$ & $b^{40} a$ & $b^{83} a$ & b & b \\
\hline РерВ & b & b & b & b & b & b & b & $\mathrm{b}$ & $\mathrm{b}$ & $\mathrm{b}$ & b & b \\
\hline PepC & b & b & b & b & b & b & $\mathrm{b}$ & b & $\mathrm{b}$ & $\mathrm{b}$ & $\mathrm{b}$ & b \\
\hline PepD & $d^{95} \mathrm{c}$ & d & - & d & d & - & d & d & d & d & d & d \\
\hline$T p i$ & $b$ & $\mathrm{~b}$ & $b$ & b & b & b & b & b & $\mathrm{b}$ & b & b & b \\
\hline
\end{tabular}


Table 3 Allozyme frequencies at 18 loci for the 15 caves within the central genetic province. Format as per Table 2.

\begin{tabular}{|c|c|c|c|c|c|c|c|c|c|c|c|c|c|c|c|}
\hline $\begin{array}{l}\text { Cave } \\
\text { Locus }\end{array}$ & $\begin{array}{l}\text { C18 } \\
(28)\end{array}$ & $\begin{array}{l}\text { C47 } \\
(18)\end{array}$ & $\begin{array}{l}\text { C56 } \\
\text { (10) }\end{array}$ & $\begin{array}{l}\text { C65 } \\
\text { (18) }\end{array}$ & $\begin{array}{c}\text { C68 } \\
(8)\end{array}$ & $\begin{array}{l}\text { C79 } \\
\text { (22) }\end{array}$ & $\begin{array}{c}\mathrm{C} 103 \\
(32)\end{array}$ & $\begin{array}{l}\text { C106 } \\
(20)\end{array}$ & $\begin{array}{l}\text { C107 } \\
(16)\end{array}$ & $\begin{array}{c}\text { C156 } \\
\text { (18) }\end{array}$ & $\begin{array}{c}\text { C159 } \\
\text { (2) }\end{array}$ & $\begin{array}{l}\text { C215 } \\
(20)\end{array}$ & $\begin{array}{l}\text { C260 } \\
\text { (12) }\end{array}$ & $\begin{array}{c}\mathrm{C} 261 \\
(2)\end{array}$ & $\begin{array}{c}\text { C281 } \\
(8)\end{array}$ \\
\hline Acon & c & $c$ & c & c & $c$ & c & $c^{34} d^{28} b^{25} e$ & $c$ & $c^{88} a^{6} b$ & $c^{67 b}$ & $\mathrm{~b}$ & c & $c^{2} b$ & - & c \\
\hline Ada & $\mathrm{f}$ & $\mathrm{f}$ & $f$ & $f$ & $f$ & $\mathrm{f}$ & f & $\mathrm{f}$ & $f$ & $\mathrm{f}$ & $f$ & $f$ & $\mathrm{f}$ & $\mathrm{f}$ & $f$ \\
\hline Adh & c & c & c & c & c & c & c & c & c & c & c & c & - & - & c \\
\hline Dia & $b^{54} d^{32} a^{11} c$ & $a^{72} c^{17 b}$ & $b$ & $b^{33} a^{28} d^{28} c$ & $d$ & $c^{45} a^{32} b^{14} d$ & b & $b^{65} d$ & $b^{58} \mathrm{~d}$ & $b^{72} d$ & $b$ & $b$ & $b^{2 / a}$ & $\mathrm{~b}$ & $\mathrm{~b}$ \\
\hline Enol & a & a & a & a & a & $\mathrm{a}$ & a & a & a & a & a & a & a & a & a \\
\hline$F d p$ & c & c & c & c & c & c & c & c & $c^{62} b$ & c & c & c & $c$ & c & c \\
\hline Fum & $b$ & $b$ & $b$ & $b$ & $\mathrm{~b}$ & $b$ & $b^{78} d$ & $b$ & $\mathrm{~b}$ & $b$ & $\mathrm{~b}$ & $b$ & $b$ & - & $b$ \\
\hline Got1 & a & $\mathrm{a}$ & $\mathrm{a}$ & a & a & a & $a$ & a & a & a & $\mathrm{a}$ & a & a & a & a \\
\hline Got2 & c & c & $c$ & $\mathrm{c}$ & c & c & $a^{94} c$ & $c$ & $c$ & $c^{56} a$ & $a^{50} \mathrm{C}$ & c & $c$ & - & c \\
\hline Gpi & $c^{61} b^{29} d$ & $b^{89} d$ & $d^{60} \mathrm{c}$ & $d^{83} \mathrm{C}$ & $c^{88} \mathrm{~d}$ & $d^{55} c^{23} e^{13} b$ & $d^{62} c$ & $c^{75} d^{10} f^{10} e$ & $d^{56} c^{31} e$ & $d^{61} c$ & $\mathrm{c}$ & $b$ & $d^{50} b^{42} c$ & $\mathrm{c}^{50} \mathrm{~d}$ & $c^{50} d^{37} b$ \\
\hline$H k$ & $b^{79} c$ & $c^{83} \mathrm{~b}$ & $\mathrm{~b}$ & $\mathrm{~b}$ & b & $b^{95} \mathrm{c}$ & $\mathrm{b}$ & b & b & b & - & $b$ & $\mathrm{~d}^{60 \mathrm{~b}}$ & - & $b^{75} d$ \\
\hline$M d h 1$ & $\mathrm{~b}$ & $b^{94} a$ & $\mathrm{~b}$ & $\mathrm{~b}$ & $b$ & $\mathrm{~b}$ & $\mathrm{~b}$ & $\mathrm{~b}$ & $\mathrm{~b}$ & $\mathrm{~b}$ & $\mathbf{b}$ & $\mathrm{b}$ & $\mathrm{b}$ & $\mathrm{b}$ & $\mathrm{b}$ \\
\hline$M d h 2$ & $c^{86} \mathrm{a}$ & $c^{83} b$ & c & $c$ & $\mathrm{c}$ & c & $\mathrm{c}$ & c & c & c & c & a & $a^{50} c$ & $c$ & $c^{62} a$ \\
\hline PepA & $\mathrm{b}$ & $\mathrm{b}$ & $b$ & $b$ & $\mathrm{~b}$ & $\mathrm{~b}$ & $\mathrm{~b}$ & b & $\mathrm{b}$ & $\mathrm{b}$ & $\mathrm{b}$ & $\mathrm{b}$ & $\mathrm{b}$ & $a^{50} b$ & $\mathrm{~b}$ \\
\hline PepB & $d^{93} \mathrm{f}$ & $d^{94} \mathrm{f}$ & $\mathrm{d}$ & $\mathrm{d}$ & $\mathrm{d}$ & $\mathrm{d}$ & $\mathrm{d}$ & $\mathrm{d}$ & $\mathrm{d}$ & $\mathrm{d}$ & $\mathrm{d}$ & $\mathrm{d}$ & $d^{67} \mathrm{c}$ & $\mathrm{d}$ & $\mathrm{d}^{5 / 5} \mathrm{c}$ \\
\hline PepC & $b^{93} a$ & $a^{94} b$ & $\mathrm{~b}^{90} \mathrm{c}$ & $\mathrm{b}$ & $c^{55 b}$ & $b^{95} \mathrm{C}$ & $b$ & b & $b^{94} \mathrm{c}$ & $\mathrm{b}$ & $b$ & $b$ & $\mathrm{~b}^{92} \mathrm{c}$ & $b$ & $\mathrm{~b}$ \\
\hline PepD & $\mathrm{d}$ & $\mathrm{d}$ & - & $\mathrm{d}$ & - & $\mathrm{d}$ & $\mathrm{d}$ & $\mathrm{d}$ & - & - & - & $\mathrm{d}$ & $\mathrm{d}$ & - & $\mathrm{d}$ \\
\hline Tpi & $b^{96} a$ & $b$ & $b$ & $b$ & $b$ & $\mathrm{~b}$ & $\mathrm{~b}$ & b & $b$ & $b$ & $b$ & $\mathrm{~b}$ & $\mathrm{~b}$ & $b$ & $\mathrm{~b}$ \\
\hline
\end{tabular}


Table 4 Allozyme frequencies at 18 loci for the nine caves within the northern genetic province. Format as per Table 2.

\begin{tabular}{|c|c|c|c|c|c|c|c|c|c|}
\hline $\begin{array}{l}\text { Cave } \\
\text { Locus }\end{array}$ & $\begin{array}{c}\text { C64 } \\
(6)\end{array}$ & $\begin{array}{c}\text { C111 } \\
(4)\end{array}$ & $\begin{array}{c}\text { C119 } \\
(2)\end{array}$ & $\begin{array}{c}\text { C227 } \\
(26)\end{array}$ & $\begin{array}{c}\text { C254 } \\
\text { (18) }\end{array}$ & $\begin{array}{l}\text { C256 } \\
(20)\end{array}$ & $\begin{array}{c}\text { C263 } \\
(22)\end{array}$ & $\begin{array}{c}\mathrm{C} 278 \\
(22)\end{array}$ & $\begin{array}{c}\text { C312 } \\
(20)\end{array}$ \\
\hline Acon & $\mathrm{d}$ & c & $\mathrm{d}$ & $\mathrm{d}$ & $\mathrm{d}$ & $d$ & $c^{\pi} d$ & c & $\mathrm{d}$ \\
\hline Ada & f & $\mathrm{f}$ & $f$ & $f$ & $\mathrm{f}$ & f & $f$ & $f$ & f \\
\hline Adh & $\mathrm{C}$ & $\mathrm{c}$ & - & c & c & $c$ & c & $c$ & c \\
\hline Dia & $\mathrm{b}$ & b & $\mathrm{b}$ & $b$ & b & $b$ & $b$ & b & $b^{90} a$ \\
\hline Enol & $\mathrm{a}$ & $a$ & a & a & $a$ & a & a & a & $\mathrm{a}$ \\
\hline$F d p$ & $b$ & b & $\mathrm{b}$ & b & $\mathrm{b}$ & b & $b^{68} a$ & b & $b^{90} a$ \\
\hline Fum & $b$ & $b$ & - & $b$ & $b^{72} a$ & $b$ & $\mathrm{~b}$ & b & $b^{80} c^{15} a$ \\
\hline Got1 & $a$ & $\mathrm{a}$ & $\mathbf{a}$ & a & a & $\mathrm{a}$ & $\mathrm{a}$ & a & a \\
\hline Got2 & $c$ & $c$ & c & $c$ & $c^{94} d$ & $\mathrm{c}$ & $d^{91} c$ & $c$ & $c^{85} d$ \\
\hline Gpi & $\mathrm{d}$ & $\mathrm{d}$ & $c^{50} d$ & $d^{54} c$ & $d^{88} b^{6} c$ & $d$ & $d^{\pi} c$ & $d^{59} c$ & $d^{65} c^{25} b$ \\
\hline$H k$ & c & - & $c$ & $c^{96} a$ & C & $c^{95} a$ & $c^{95} b$ & $c^{60} b^{35} a$ & $c$ \\
\hline MdhI & $b$ & b & $\mathrm{b}$ & $b$ & b & b & $b^{95} c$ & b & $b$ \\
\hline$M d h 2$ & $e^{67} c$ & e & $c$ & $c^{50} e^{42} f$ & $\mathrm{f}^{83} \mathrm{c}^{11} \mathrm{e}$ & $\mathrm{f}^{85} \mathrm{C}$ & $f^{81} c^{14} d$ & $\mathrm{f}^{86} \mathrm{c}$ & $f^{60} e^{30} a^{5} c$ \\
\hline PepA & b & - & $b$ & b & b & $\mathbf{b}$ & b & $\mathrm{b}$ & b \\
\hline$P e p B$ & $\mathrm{~d}$ & d & $\mathrm{d}$ & $d^{85} e$ & $d$ & $\mathrm{~d}$ & $d^{77} f$ & $d$ & $d^{90} \mathrm{c}$ \\
\hline PepC & $b$ & $b$ & $b$ & $\mathrm{~b}$ & $b$ & b & $\mathrm{b}$ & $\mathbf{b}$ & $\mathrm{b}$ \\
\hline PepD & - & a & - & $a^{77} d^{19} b$ & $a^{83} d$ & $b^{55} a$ & $a$ & $b^{55} a$ & $a$ \\
\hline$T p i$ & $c^{83} b$ & b & $c$ & $b^{65} c$ & $c^{61} b^{22} a$ & $c^{90} b$ & $b^{82} c$ & $b^{86} c$ & $c^{65 b}$ \\
\hline
\end{tabular}

structuring within caves and indicate that caves may be treated as the unit of analysis.

Analyses of the within-cave tests of linkage disequilibrium showed that none of the 36 individual populations displayed any significant association between genotypes at different loci (all $\mathrm{P}$-values $>0.067$ before correction). Furthermore, none of the 18 loci in a multi-population test (Fisher's method) displayed any evidence of genotypic disequilibrium (lowest $P$-value $=0.131$ ). Hence, these analyses indicate that each of the loci examined allows an independent test of population structure.

\section{Genetic provinces}

Analysis of the genetic distance matrix between all 36 populations (the matrix including Nei's Genetic Distance and \% Fixed Differences is given in Humphreys and Shear [1993]) provides unequivocal evidence that the populations have not been taken from a single gene pool. Three major genetic groupings emerge (Figure 4): a southern group (to the south of Mount Hollister in caves C$15,62,118,126,151,154,161,162,163,167,171$ and 207 ), a northern group (from the most westerly branch of Shothole Canyon northeastwards in caves C-64, 111, 119, 227, 254, 256, 263, 278 and 312) and a central group in caves C-18, 47, 56, 65, 68, 79, 103, $106,107,156,159,215,260,261$ and 281).

The southern genetic province (Figure 3 ) includes an outlying population (C-203; only included in the pilot study) that is well separated from the main cluster of caves by extensive fixed red sand-dunes of Pleistocene age (Wyrwoll et al., 1993) implying a previous even more arid climate. The northern genetic province includes the distant outlier C-111 in an isolated surface exposure of Tulki Limestone. The boundaries of the central genetic province (Figure 3) are loosely associated with gorges that have cut through the cavernous Tulki Limestone into the noncavernous Mandu Limestone below (Condon et al., 1955). Stygiochiropus communis from the three genetic provinces will hereafter be treated as separate taxonomic units and those caves represented by small sample size $(n<4)$ will mostly be excluded from further analysis.

\section{Pairwise between-cave comparisons of allele frequency}

Panmixia results from a sufficiently high rate of gene flow, whereas if gene flow is sufficiently low then natural selection and genetic drift may occur more or less independently in each deme (Slatkin, 1981). An unambiguous way to show that populations are genetically isolated from each other would be to find loci which are fixed for different alleles or have a high frequency of private alleles (Singh and Rhomberg, 1987). Nevertheless, genetic substructuring can also be demonstrated by statistically significant differences in allele frequency, and the importance of this component increases with fragmentation of the habitat and isolation of the populations (Sarre et al., 1990).

A large number of significant differences in allele frequency were evident between caves within each province. These are summarised in Tables 5-7. In many cases these differences involve caves being fixed for different alleles (Figure 4a), but there are also occasional examples of a single cave displaying a high frequency of a private allele. The data reveal that there is unequivocal genetic substructuring 
a

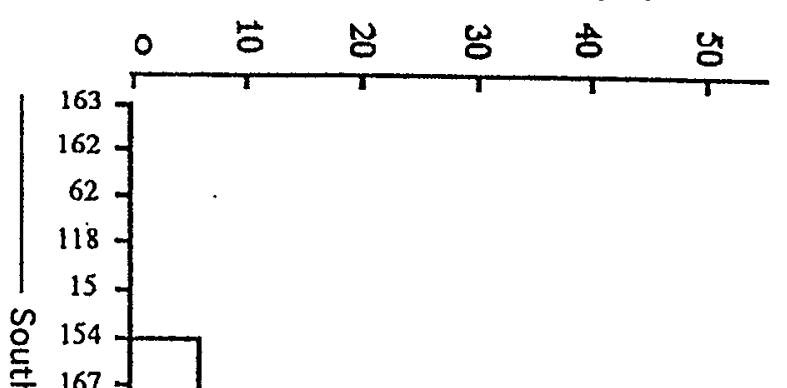

b

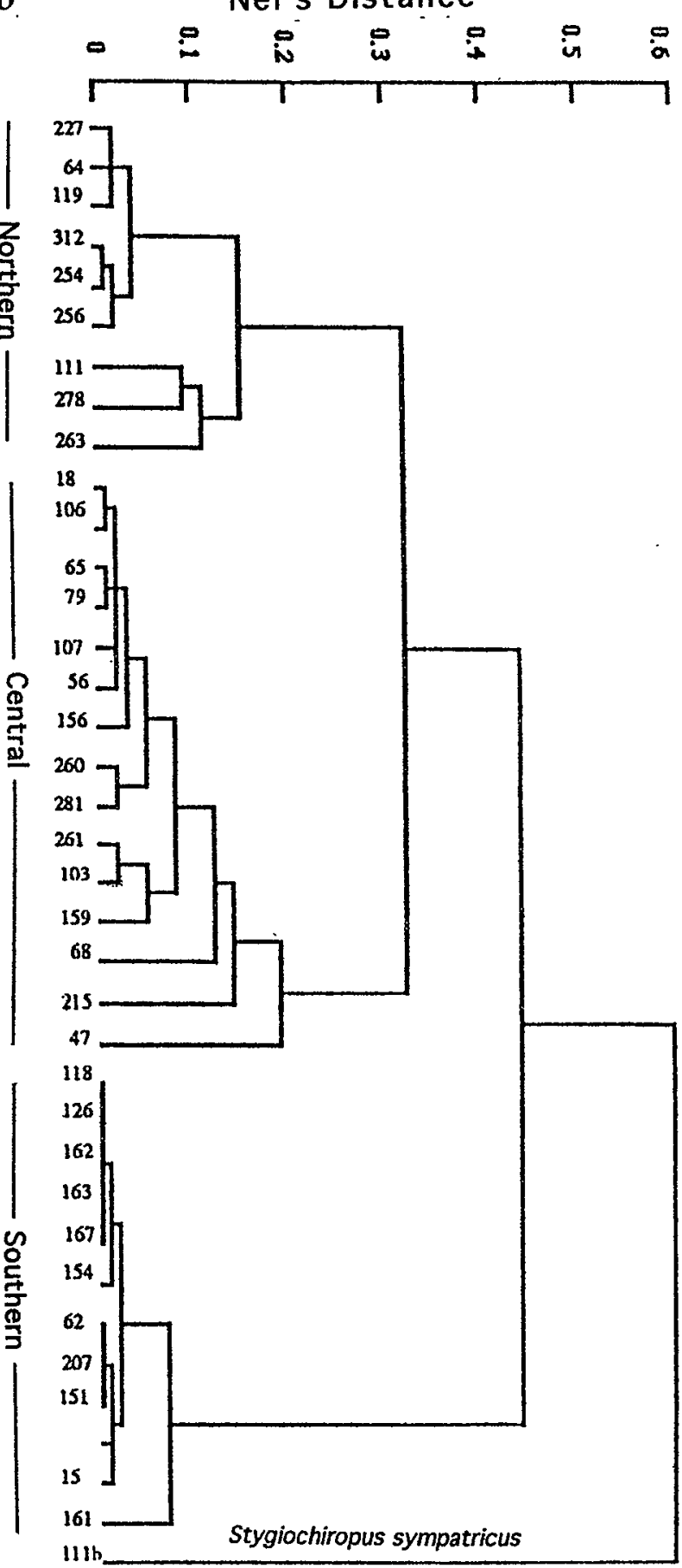

Figure 4 UPGMA phenograms showing the genetic relationships between populations of $S$. communis from 36 caves in Cape Range: a, \% fixed differences; b, Nei's distance corrected for small sample size (Nei, 1978).

within each province at a minimum of two loci, and that adjacent caves often display fixed differences, thus precluding a simple isolation-by-distance model within any province.

Only two loci (Ada and $A d h$ ) showed significant differences between caves in the southern province, with $A d a$ accounting for $65 \%$ of all such cases (Table 5). Apart from four instances where cave C-161 differed at both loci from other populations, all other comparisons resulted in either no heterogeneity or a single significant difference. In contrast, the other two provinces were considerably more genetically heterogeneous. Caves within the central province were distinguishable from one another by various combinations of seven loci (Acon, Dia, Got2, Gpi, Hk, Mdh2, and PepC; Table 6) whilst the northern province displayed heterogeneity at six loci (Acon, Got2, Gpi, Mdh2, 
Table 5 Pairwise comparisons of allele frequency between caves in the southern province. Lower triangle - the number of significant differences; upper triangle - lists the loci involved.

\begin{tabular}{|c|c|c|c|c|c|c|c|c|c|}
\hline $\begin{array}{l}\text { Cave } \\
\mathrm{N}\end{array}$ & $\begin{array}{l}\text { C15 } \\
\text { (10) }\end{array}$ & $\begin{array}{c}C 126 \\
(12)\end{array}$ & $\begin{array}{c}\text { C154 } \\
(7)\end{array}$ & $\begin{array}{c}\text { C161 } \\
(9)\end{array}$ & $\begin{array}{c}\text { C162 } \\
(7)\end{array}$ & $\begin{array}{c}\text { C163 } \\
(10)\end{array}$ & $\begin{array}{c}\mathrm{C} 167 \\
(6)\end{array}$ & $\begin{array}{c}\text { C171 } \\
(9)\end{array}$ & $\begin{array}{c}\mathrm{C207} \\
\text { (10) }\end{array}$ \\
\hline $\mathrm{C} 15$ & - & - & Ada & $A d h$ & - & Ada & - & - & - \\
\hline C126 & 0 & - & - & Ada Adh & - & - & - & Ada & Ada \\
\hline C154 & 1 & 0 & - & Ada Adh & - & - & - & Ada & Ada \\
\hline C161 & 1 & 2 & 2 & - & Ada Adh & Ada Adh & $A d h$ & $A d h$ & Adh \\
\hline C162 & 0 & 0 & 0 & 2 & - & - & - & Ada & $A d a$ \\
\hline $\mathrm{C} 163$ & 1 & 0 & 0 & 2 & 0 & - & - & Ada & Ada \\
\hline C167 & 0 & 0 & 0 & 1 & 0 & 0 & - & - & Ada \\
\hline C171 & 0 & 1 & 1 & 1 & 1 & 1 & 0 & - & - \\
\hline C207 & 0 & 1 & 1 & 1 & 1 & 1 & 1 & 0 & - \\
\hline
\end{tabular}

Caves where $\mathrm{N}<4(\mathrm{C} 62(\mathrm{~N}=1) \mathrm{C} 118(\mathrm{~N}=1)$ and $\mathrm{C} 151(\mathrm{~N}=2))$ are excluded from the analysis as presented. If these caves are included then none displays any significant difference in allele frequency from any other.

PepD, and Tpi; Table 7). Both provinces exhibited numerous cases of cave populations exhibiting differences at multiple loci, with caves C-47, C-103, and $C-215$ in the central province and caves C-263, and $\mathrm{C}-278$ in the northern province accounting for much of this heterogeneity (Tables 6 and 7).

The average level of genetic divergence between pairwise comparisons of caves within a province also shows a significant increase from south to north, both for \% FD and Nei D (Table 8). Given that $S$. communis is restricted to caves, this suggests that subterranean connections are better developed and more integrated towards the south as would be expected from a more mature karst drainage system and this is supported by the geomorphological evidence (see below).

The mean $25.6 \%$ FD between groups (Table 8 ) is much greater than that within groups $(0.9-3.1 \%$ FD; Table 8). Interestingly, populations showing the highest levels of within-province genetic divergence are not necessarily those located on the periphery of the province. Thus, for example, the population from C-161 shows the greatest level of genetic divergence from all others in the southern province (Figure 4a) and yet is only $700 \mathrm{~m}$ from C-15, while the outlying population C-203 is genetically close to that in C-15 from which it is separated by a distance of c. $26 \mathrm{~km}$. In the central province the genetically distinctive outlier population from C-215 (Table 6) nevertheless shows no fixed differences from C-260, despite being separated by $7.3 \mathrm{~km}$.

Mean Nei's distance in the southern province is lower than in either the central or northern provinces and again shows that the southern province is genetically more homogeneous (Table 8). Mean Nei's distance between provinces is substantially greater than that within provinces (Table 8), as with \% FD. Phenograms based on \% FD and on Nei's distance
(Figures 4a, 4b) reveal more details in the structure of the populations within Cape Range. For example, in the northern genetic province C-278 and C-263 are physically peripheral to the main distribution of northern caves and this is reflected in both the phenogram (Figure $4 \mathrm{~b}$ ) and the pairwise comparisons (Table 7). Similarly there is agreement with the physical location of C-47 and C-215 in the central province, and between C-15 and C-161 in the south (Figure $4 b$ ).

The apparent differences between the provinces for between-cave genetic diversity do not appear to result from great disparity in sampling either for total area, the number of caves, the number of individuals or the number of alleles per locus (Table 9). This increase in genetic diversity from south to north correlates with an assessment of the geomorphological heterogeneity of the areas (Table 10).

Despite the lithological diversity in Cape Range, troglobites have been found more or less exclusively in caves formed in Tulki Limestone which is cut through in places by gorges penetrating to the underlying marly Mandu Limestone. The main difference between the areas of relevance to panmixia is the degree to which gorges penetrate to the non-cavernous Mandu Limestone (high in the central province) and which thus forms barriers to migration between cave systems. Where there is greater geomorphological diversity (Table 10) there is greater genetic heterogeneity which does not result from a change in the number of alleles per locus (Table 9). Together these data suggest that caves in the southern province are more connected than those in either the central or the northern provinces.

If these findings are generally applicable to the diverse cave fauna of Cape Range then this has 
Table 6 Pairwise comparisons of allele frequency between caves in the central province. Format as per Table 5.

\begin{tabular}{|c|c|c|c|c|c|c|c|c|c|c|c|c|c|}
\hline $\begin{array}{l}\text { Cave } \\
\mathrm{N}\end{array}$ & $\begin{array}{l}\text { C18 } \\
(14)\end{array}$ & $\begin{array}{l}\text { C47 } \\
(9)\end{array}$ & $\begin{array}{c}\text { C56 } \\
(5)\end{array}$ & $\begin{array}{l}\text { C65 } \\
(9)\end{array}$ & $\begin{array}{l}\text { C68 } \\
(4)\end{array}$ & $\begin{array}{l}\text { C79 } \\
(11)\end{array}$ & $\begin{array}{c}\text { C103 } \\
(16)\end{array}$ & $\begin{array}{c}\text { C106 } \\
(10)\end{array}$ & $\begin{array}{c}\text { C107 } \\
(8)\end{array}$ & $\begin{array}{c}\text { C156 } \\
(9)\end{array}$ & $\begin{array}{l}\text { C215 } \\
(10)\end{array}$ & $\begin{array}{c}C 260 \\
(6)\end{array}$ & $\begin{array}{c}\text { C281 } \\
(4)\end{array}$ \\
\hline $\mathrm{C} 18$ & - & $\begin{array}{l}\text { Dia Gpi } \\
\text { Hk PepC }\end{array}$ & - & $\begin{array}{c}\text { Gpi } \\
-\end{array}$ & $\begin{array}{c}\text { PepC } \\
-\end{array}$ & $\begin{array}{c}\text { Dia } \\
-\end{array}$ & $\begin{array}{l}\text { Acon Dia } \\
\text { Got2 Gpi }\end{array}$ & - & Gpi & Got2 & Gpi Mdh2 & - & - \\
\hline C47 & 4 & $\begin{array}{l}\bullet \\
-\end{array}$ & $\begin{array}{l}\text { Dia Gpi } \\
\text { Hk PepC }\end{array}$ & $\begin{array}{c}\text { Gpi Hk } \\
\text { PepC }\end{array}$ & $\begin{array}{l}\text { Dia Gpi } \\
\text { Hk PepC }\end{array}$ & $\begin{array}{c}\text { Gpi Hk } \\
\text { PepC }\end{array}$ & $\begin{array}{l}\text { Acon Dia } \\
\text { Got2 Gpi } \\
\text { Hk PepC }\end{array}$ & $\begin{array}{l}\text { Dia Gpi } \\
\text { Hk PepC }\end{array}$ & $\begin{array}{l}\text { Dia Gpi } \\
\text { Hk PepC }\end{array}$ & $\begin{array}{l}\text { Dia Gpi } \\
\text { Hk PepC }\end{array}$ & $\begin{array}{c}\text { Dia Hk } \\
\text { Mdh2 PepC }\end{array}$ & $\begin{array}{c}\text { Dia Hk } \\
\text { PepC }\end{array}$ & $\begin{array}{c}\text { Dia Hk } \\
\text { PepC }\end{array}$ \\
\hline C56 & 0 & 4 & - & & Dia & Dia & Got2 & - & - & - & Gpi Mdh2 & - & - \\
\hline C65 & 1 & 3 & 0 & - & PepC & - & $\begin{array}{l}\text { Acon Dia } \\
\quad \text { Got2 }\end{array}$ & Gpi & - & - & $\begin{array}{c}\text { Dia Gpi } \\
M d h 2\end{array}$ & - & - \\
\hline C68 & 1 & 4 & 1 & 1 & - & Dia & $\begin{array}{c}\text { Dia Got2 } \\
\text { PepC }\end{array}$ & PepC & - & PepC & $\begin{array}{c}\text { Dia Gpi } \\
\text { Mdh2 PepC }\end{array}$ & Dia & Dia \\
\hline C79 & 1 & 3 & 1 & 0 & 1 & - & $\begin{array}{l}\text { Acon Dia } \\
\text { Got2 }\end{array}$ & Dia & - & Dia & $\begin{array}{c}\text { Dia Gpi } \\
\text { Mdh2 }\end{array}$ & Dia & Dia \\
\hline $\mathrm{C} 103$ & 4 & 6 & 1 & 3 & 3 & 3 & - & $\begin{array}{c}\text { Acon Got2 } \\
\text { Gpi }\end{array}$ & Got2 & Got2 & $\begin{array}{c}\text { Acon Gpi } \\
\text { Got2 Mdh2 }\end{array}$ & Got2 Hk & Got2 \\
\hline C106 & 0 & 4 & 0 & 1 & 1 & 1 & 3 & 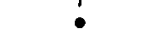 & - & - & Gpi Mdh2 & Gpi Hk & - \\
\hline $\mathrm{C} 107$ & 1 & 4 & 0 & 0 & 0 & 0 & 1 & 0 & - & - & Gpi Mdh2 & - & - \\
\hline C156 & 1 & 4 & 0 & 0 & 1 & 1 & 1 & 0 & 0 & - & Gpi Mdh2 & - & - \\
\hline $\mathrm{C} 215$ & 2 & 4 & 2 & 3 & 4 & 3 & 4 & 2 & 2 & 2 & • & - & - \\
\hline $\mathrm{C} 260$ & 0 & 3 & 0 & 0 & 1 & 1 & 2 & 2 & 0 & 0 & 0 & - & - \\
\hline C281 & 0 & 3 & 0 & 0 & 1 & 1 & 1 & 0 & 0 & 0 & 1 & 0 & - \\
\hline
\end{tabular}

Caves where $\mathrm{N}<4(\mathrm{C} 159(\mathrm{~N}=1) \mathrm{C} 261(\mathrm{~N}=1))$ were excluded from the analysis as presented. If these caves are included then neither displays any significant differences in allele frequency from any other. 
Table 7 Pairwise comparisons of allele frequency between caves in the northern province. Format as per Table 5.

\begin{tabular}{|c|c|c|c|c|c|c|}
\hline $\begin{array}{l}\text { Cave } \\
\mathbf{N}\end{array}$ & $\begin{array}{c}\text { C227 } \\
\text { (13) }\end{array}$ & $\begin{array}{c}\text { C254 } \\
(9)\end{array}$ & $\begin{array}{c}C 256 \\
\text { (10) }\end{array}$ & $\begin{array}{c}\mathrm{C} 263 \\
(11)\end{array}$ & $\begin{array}{c}\mathrm{C} 278 \\
(\mathbf{1 1})\end{array}$ & $\begin{array}{c}\text { C312 } \\
\text { (10) }\end{array}$ \\
\hline \multirow[t]{2}{*}{$\mathrm{C} 227$} & - & $M d h 2$ & Gpi Mdh2 & Acon Got2 & Acon $M d h 2$ & Mdh2 \\
\hline & & PepD Tpi & $M d h 2$ & PepD & & \\
\hline \multirow[t]{2}{*}{ C254 } & 1 & - & PepD & Acon Got2 & Acon Tpi & - \\
\hline & & & $T p i$ & PepD & - & \\
\hline \multirow[t]{2}{*}{ C256 } & 4 & 1 & - & Acon Got2 & Acon Tpi & PepD \\
\hline & & & PepD Tpi & & & \\
\hline C263 & 3 & 3 & 4 & - & Got2 PepD & Acon Got2 \\
\hline $\mathrm{C} 278$ & 3 & 3 & 2 & 2 & - & Acon PepD2 \\
\hline C312 & 1 & 0 & 1 & 2 & 2 & - \\
\hline
\end{tabular}

Caves where $\mathrm{N}<4$ are excluded from analysis as presented. If these caves are included then: $\mathrm{C} 64(\mathrm{~N}=3)$ is significantly different from C256 (Mdh2) C263 (Got2 Mdh2) and C278 (Acon Mdh2); C111 (N=2) is significantly different from C227 (Acon) C254 (Acon) C256 (Acon Mdh2) C263 (Mdh2) C278 (Mdh2) and C312 (Mdh2); C119 (N=1) is not significantly different from any other cave.

Table 8 The distances, both metric $(\mathrm{km})$ and genetic (\% fixed genetic differences and corrected Nei's distance; Nei, 1978) between all pairs of caves from which millipede electrophoretic samples were derived in the southern, central and northern genetic provinces of Cape Range. Common letters within columns (upper four rows only) denote no significant difference (ANOVA followed by Fisher's PLSD; $\alpha=0.05$ ).

\begin{tabular}{|c|c|c|c|c|c|c|}
\hline \multirow{2}{*}{ Comparison } & \multicolumn{3}{|c|}{ Distance (km) } & \multirow[b]{2}{*}{ Range } & \multirow{2}{*}{$\begin{array}{l}\text { FD\% } \\
\text { Mean }\end{array}$} & \multirow{2}{*}{$\begin{array}{c}\text { Nei's D } \\
\text { Mean }\end{array}$} \\
\hline & *Mean & S.D. & $\mathbf{N}$ & & & \\
\hline Within Southern Group & $3.51 \mathrm{a}$ & 2.50 & 66 & $0.23-7.7$ & 0.92 & 0.021 \\
\hline Within Central Group & $4.10 \mathrm{a}$ & 2.88 & 105 & $0.03-13$ & 2.59 & $0.094 a$ \\
\hline Within Northern Group & $5.24 \mathrm{a}$ & 4.88 & 36 & $0.03-16.2$ & 3.06 & $0.101 \mathrm{a}$ \\
\hline Between Groups & 10.55 & 5.58 & 423 & - & 25.58 & 0.400 \\
\hline South North & - & - & - & $8.9-32.6$ & - & - \\
\hline South Central & - & - & - & $2.3-20.9$ & - & - \\
\hline North Central & - & - & - & $1.2-22.7$ & - & - \\
\hline
\end{tabular}

ANOVA's: Distance: $-F_{3,32}=79.67, P<0.001$. Fixed differences $\left(\log +1\right.$ transformation): $F_{3,32}=803.6, P<0.001$; follow-up test is Fishers PLSD based on log transformed data. Nei's distance: $F_{3,32}=577.9, P<0.001$. Number of loci different: $F_{2,28}=$ 8.389, $\mathrm{P}<0.005$; follow-up test is Fishers PLSD. Each point represents a comparison between two of $\mathrm{n}$ populations and there are $n(n-1) / 2$ points; these are not statistically independent hence the degrees of freedom in the above analyses are based on $n$ caves rather than $n(n-1) / 2$ comparisons.

Table 9 The area of each province is given together with the number of alleles at each of 15 polymorphic loci and the sample size per cave per locus. Statistics for the comparison of the means are given below \pm the standard error.

\begin{tabular}{lcccc}
\hline & \multicolumn{3}{c}{ Genetic province } & \\
Parameter & South & Central & North & All \\
\hline Area $\left(\mathrm{km}^{2}\right)$ & 397 & 117 & 257 & - \\
No. alleles / locus & $2.3 \pm 0.34$ & $2.6 \pm 0.32$ & $2.4 \pm 0.29$ & $4.3 \pm 0.34$ \\
N / locus/cave & $6.8 \pm 1.08$ & $7.7 \pm 1.11$ & $7.7 \pm 1.52$ & - \\
No. caves & 12 & 15 & 9 & - \\
Loci Hardy-Weinberg & $33 \%$ & $100 \%$ & $67 \%$ & - \\
\hline
\end{tabular}

\footnotetext{
${ }^{1}$ The mean number of alleles per locus: $\mathrm{F}_{1,52}=0.45, \mathrm{P}=0.51$.

2 The mean number of individuals per locus per cave: $F_{2,33}=0.18, P=0.83$
} 
Table 10 Some characteristics of the three genetic provinces ranked according to their geomorphological complexity based on the 'surface geology maps (Condon et al., 1955) and on older karst (on an anticline higher is older) having more ${ }^{2}$ integrated drainage (Hamilton-Smith et al. 1998).

\begin{tabular}{lccc}
\hline & \multicolumn{3}{c}{ Genetic province } \\
Characteristic & South & Central & North \\
\hline${ }^{1}$ Exposures of Mandu Limestone & 1 & 3 & 2 \\
${ }^{1}$ Number of rock types exposed & 1 & 2 & 3 \\
${ }^{1}$ Rank patchiness of Tulki Limestone & 1 & 2 & 3 \\
${ }^{2}$ Lack of karst integration & 2 & 1 & 3 \\
\hline Mean rank & 1.25 & 2.00 & 2.75 \\
\hline
\end{tabular}

The southern area is more geologically homogeneous than the two other areas: Kruskal-Wallis test $\mathrm{H}_{c}=6.308$ with $2 \mathrm{df}$ $(\mathrm{P}<0.05)$. ${ }^{3} \mathrm{Tulki}$ Limestone contains the main cave development, while the underlying marly Mandu Limestone acts as an aquitard.

important implications to the overall management of the karst region; as discussed earlier, data for Schizomida and Amphipoda are consistent with this interpretation (Humphreys and Adams, 1991; Adams and Humphreys, 1993).

This finding is also consistent with a geomorphological interpretation of the Cape Range karst. Cape Range reaches its maximum height (314 m) at Mount Hollister, which approximates the divide between the central and southern genetic provinces. The axis of the Cape Range anticline plunges gently northwards and the overlying strata should progressively have been stripped downslope and down the hydraulic gradient. In consequence the Tulki Limestone to the south will have been exposed to karstification longer than that to the north and so the southern part of the range should have the oldest, best developed and most integrated karst (Hamilton-Smith et al., 1998: 1516). The integrated open subterranean conduit system characteristic of such mature karst will facilitate movement of subterranean species between caves and result in more opportunities for panmixia. The lesser integration of the karst in the central and northern provinces results both from its relative immaturity and from the dissection of the cavernous limestone by deep gorges penetrating to the underlying non-cavernous strata.

The mean metric distances separating caves within the three provinces do not differ significantly from one another (Table 8). Importantly, the known minimum distances separating caves containing millipedes between adjacent genetic provinces are $1.23 \mathrm{~km}$ between the northern and central groups, and $2.36 \mathrm{~km}$ between the southern and central groups; these distances are small compared with the mean distance between caves within provinces
(Table 8). Hence, the evidence suggests that the genetic provinces have distinct boundaries.

\section{Genetic relationships amongst caves within a province}

Multidimensional scaling (MDS) was conducted on the Rogers' genetic distance matrices within provinces to display the genetic affinities amongst populations (Figure 5)

All three provinces have a cluster of genetically similar populations and a number of outliers, these being most varied in the central province which has the most complex geomorphology. The major features of MDS within each province are outlined below.

\section{Southern Province (Table 5, Figure 5a)}

Cave C-161 displays 6\% FD from other caves in the southern province and is the only cave represented that lies within the Yardie Creek surface drainage. Of the other outlying populations, the pair of caves C-15 and C-207 uniquely lie in drainage flowing southeast past Trealla Hill, while C-154, and possibly C-171, drain west to Mandu Mandu gorge. All the other caves in the southern province lie in surface catchments flowing east. Indeed, there is evidence from the location of the leads that C-126, 162, 163 and 167, which all form a tight cluster following MDS, are probably part of the same system.

\section{Central Province (Table 6, Figure 5b)}

The genetic heterogeneity in these populations is chaotic with respect to the geomorphology and the numerous fixed difference clearly refute the isolation by distance model.

Considering the genetic outliers, cave C-215 lies near the west coast, more than $6.5 \mathrm{~km}$ distant from all remaining populations in the central province, and yet it exhibits no fixed differences from some populations whereas it differs by up to $19 \% \mathrm{FD}$ from others. Conversely, C-281 and C-260 are only $300 \mathrm{~m}$ apart but they lie on separate catchments with C-281 draining to an unnamed gorge leading to the Milyering Centre, and in which C-215 also lies, while $\mathrm{C}-260$ and $\mathrm{C}-47$ drain respectively into the extreme northern and southern branches of RAAF Canyon.

Turning to the caves which loosely cluster together in Figure 5b, the group C-68, 103, 107 and 156 drain westwards, C-68 drains to the unnamed gorge opening at Tulki Beach, while C-103, 107 and 156 also drain westward, to Mandu Mandu gorge, the next gorge to the south. The group C-18, 56, 65 , 79 and 106 lies in eastward drainages, C-106 is in the catchment for Shothole Canyon, C-79 and 65 lie on the same upper branch of an eastward draining gorge, and C-18 and 56 are both probably in eastern drainages. 


\section{a) southern province}

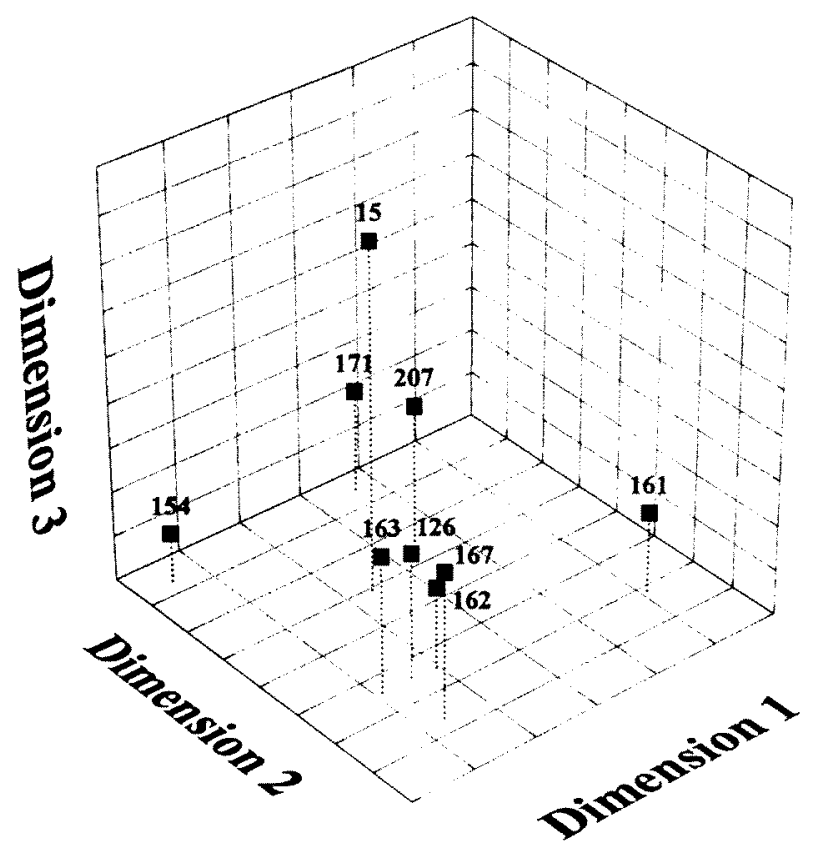

b) central province



c) northern province

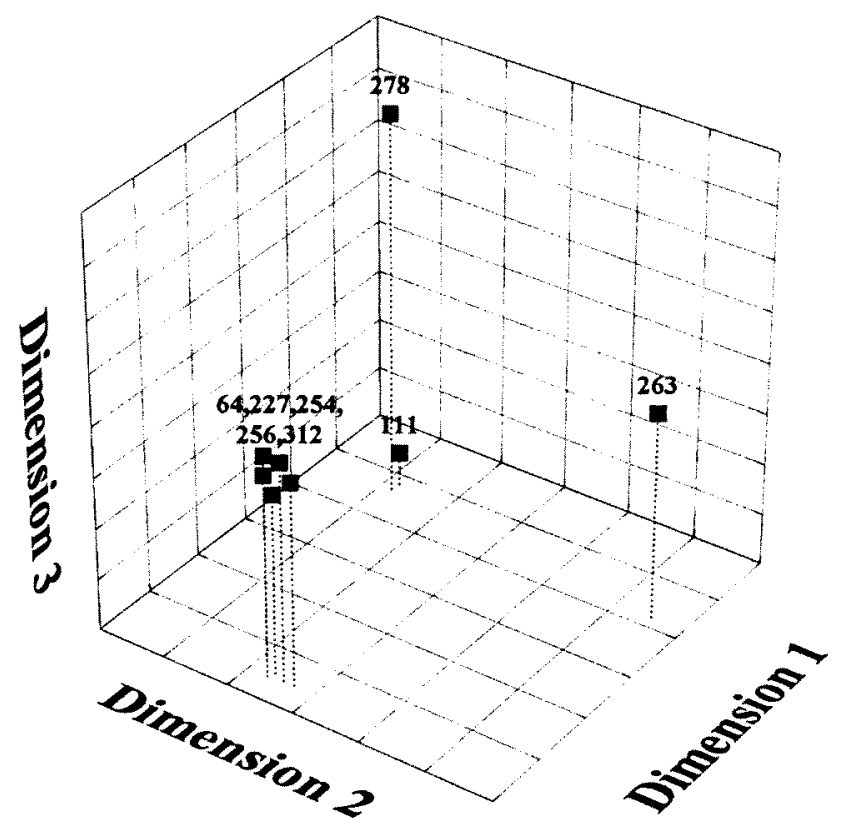

Figure 5 Multidimesional scaling (MDS) based on the Rogers' genetic distance matrices for Stygiochiropus communis within provinces: (a), southern province; (b), central province; (c), northern province.

We infer from these data that there is greater genetic interchange between caves within catchments and thus probably some concordance between the surface drainages (discussed here) and the subterranean drainage system, often not the case in karst terrains (Ford and Williams, 1989).
Northern Province (Table 7, Figure 5c)

There are a number of geographical outliers in the northern province. $\mathrm{C}-111$ and $\mathrm{C}-278$ have from $6 \%$ to $13 \% \mathrm{FD}$ from any other populations in the northern province, but C-263 is also an outlier. C111 is far removed (c. $11 \mathrm{~km}$ ) from the main cluster 
of caves, while C-278 lies at the far western extent of the province where it is nearly isolated by gorges from the remainder of the cave populations in the genetic province. By contrast, C-263 is the sole population northeast of a gorge cutting down through Mandu Limestone but it is separated by only c. $800 \mathrm{~m}$ from C-256 which itself forms part of the main cluster in Figure 3. However, C-256 itself is separated by a major gorge and c. $2.5 \mathrm{~km}$ from C254 , the closest of the remaining caves in the main cluster.

The connections between cave populations suggested by the genetic data indicate that both deep gorges and surface drainage basins are influential in determining the interconnectedness of the millipede populations. The gorges often cut into the non-cavernous Mandu Limestone and so here the mechanism of the disjunctions is clear. In addition, the association of genetic clusters with the surface drainage suggests that the underground drainage - providing presumed conduits for genetic interchange - reflect the surface drainage. This inference is not trivial, since surface and subterranean drainages are often discordant in karst areas (Ford and Williams, 1989).

\section{Gene flow estimates}

The average gene flow, expressed as the number of migrants per generation $(\mathrm{Nm})$ can be estimated from Wright's statistic, $F_{S T}$ (Slatkin, 1981). Alternatively, $\mathrm{Nm}$ can be estimated from the number of rare alleles (for neutral alleles $F_{5 T}=1$ / $(1+4 \mathrm{Nm})$; Slatkin, 1985). In an island population model $N m$ represents the average number of individuals exchanged between populations in each generation; populations do not diverge unless $\mathrm{Nm}$ $<1$ (Wright, 1931). Generally, if $\mathrm{F}_{\mathrm{ST}}>0.2(\mathrm{Nm}<1)$ populations will continue to diverge, and with values of $\mathrm{F}_{\mathrm{ST}}>0.33(\mathrm{Nm}<0.5)$ populations will be essentially unconnected genetically (Trexler, 1988; Slatkin and Barton, 1989). However, in the case of drift, the rule of thumb is that one immigrant every second generation or one interpopulation mating per generation $(\mathrm{Nm}=0.5)$ will be sufficient to prevent strong differentiation. This result is independent of population size (Ellastrand and Elam, 1993).

We estimated the rate of gene flow between caves within genetic provinces, deriving $\mathrm{Nm}$ from Wright's statistic $\left(\mathrm{F}_{\mathrm{ST}}\right)$ to calculate the standardized variance in allele frequencies. The average $\mathrm{Nm}$ values were statistically similar in the central and northern provinces (Table 11), but in the southern province $\mathrm{Nm}$ was significantly greater, suggesting substantially more gene flow between the southern populations (Table 11). The high level of genetic interchange between populations within the southern genetic province is to be expected from the overall genetic similarity of the populations. In the central and northern genetic provinces, the genetic interchange between caves is low and on average only marginally sufficient to prevent divergence between the populations (Table 11). However, the minimum $N m$ values (Table 11) imply that within each of the genetic provinces gene flow is insufficient to prevent genetic divergence between certain cave populations. These populations possibly represent the initial stages of

Table 11 The average gene flow, expressed as the number of migrants per generation $(\mathrm{Nm})$ in comparisons between all caves within each genetic province excluding comparisons of populations with fixed differences. a) $\mathrm{Nm}$ is derived using Wright's (1931) statistic to calculate the standardised variance in allele frequencies. Asterisks denote correction in the degrees of freedom for multiple cave comparisons. Common letters within a column denote no significant difference (ANOVA followed by Fisher's PLSD; $\mathrm{a}=0.05$ ). b) $\mathrm{Nm}$ estimated using the private allele methods calculated using GENEPOP according to Barton and Slatkin (1986).

a)

\begin{tabular}{lcccccc}
\hline Province & Mean Nm & S.E. & $\mathbf{N}$ & ${ }^{*} \mathbf{N}$ & $\mathbf{9 5 \%}$ limits & Range \\
\hline South & 6.485 & 1.250 & 55 & 11 & $3.98-8.99$ & $0.26-52.3$ \\
Central & $1.606 \mathrm{a}$ & 0.153 & 66 & 12 & $1.08-2.34$ & $0.36-4.98$ \\
North & $1.707 \mathrm{a}$ & 0.302 & 21 & 7 & $1.30-1.91$ & $0.21-5.82$ \\
\hline
\end{tabular}

ANOVA $-\mathrm{F}_{2,27}=11.57, \mathrm{P}<0.001$.

b)

\begin{tabular}{lccc}
\hline Parameter & Province & \\
& Northern & $\begin{array}{c}\text { Central } \\
\text { Southern }\end{array}$ \\
\hline Mean sample size & 7.952 & 7.926 & 6.889 \\
Mean frequency of private alleles $p(1)$ & 0.115 & 0.192 & 0.076 \\
Number of migrants after correction for sample size & 1.182 & 0.418 & 3.205 \\
$\% \mathrm{~F}_{\mathrm{ST}}$ method (Table 7) & 69 & 26 & 49 \\
\hline
\end{tabular}


population divergence before fixed differences become established, as has occurred already for some of the existing populations within each genetic province.

$\mathrm{Nm}$ can also be independently estimated using the private allele method (Barton and Slatkin, 1986). For the millipede data, this estimate of $\mathrm{Nm}\left(\mathrm{Nm}_{\mathrm{p}}\right)$ provides lower values (between 26-69\% lower; Table 11) than those derived using Wright's statistic $\left(N m_{\mathrm{F}}\right)$.

Examination of the relationship between $N m_{\mathrm{F}}$ and $N m_{\mathrm{p}}$ (excluding comparisons with fixed differences) shows that the regressions of $\log N m_{\mathrm{p}}$ on $\log N m_{\mathrm{F}}$ are significant for all three genetic provinces and that the regression lines do not differ in slope ( $F s_{2,12}=0.76, P=0.49$ ) or intercept $\left(F_{2,14}=3.187, \mathrm{P}=0.073\right.$ ). The common regression $\log N m_{\mathrm{p}}=1.04 \log \mathrm{F}_{\mathrm{ST}}-0.35\left(\mathrm{r}^{2}=0.78, \mathrm{ts}_{16}=7.48\right.$, $\mathrm{P}<0.001)$ has a slope of 1 indicating that the two methods of determining $\mathrm{Nm}$ scale equally but differ by a constant factor. The analysis again suggests that the gene flow between populations is higher in the southern province than in either of the other two area $(\mathrm{P}<0.05)$. Note that Slatkin's (1985) method is particularly sensitive to the presence in a given population of a high frequency of private alleles (Slatkin, 1987) and can thus mask gene flow between other populations.

Nonetheless, while there is some degree of heterogeneity in the genetic interchange within all three provinces, the southern province is clearly more interconnected than the two northern provinces and this is in accord with the geomorphological interpretation. Gene flow appears sufficiently low to permit divergence between some cave populations, especially in the two more northerly provinces.
The $N m$ values encountered here for cave populations within provinces $\left(\mathrm{N} m_{\mathrm{F}}=1.6\right.$ to 6.5 over an mean distance of $4.1 \mathrm{~km}$ ) are comparable to those estimated for many other cave-restricted lineages. For example, a study of 25 populations comprising five species of Hadenoecus crickets found $\mathrm{Nm}$ values between 0.67 and 22.51 (Caccone and Sbordoni, 1987). Indeed, the same study estimated even lower levels of gene flow for other troglobitic taxa such as Euhadeneocus fragilis $(\mathrm{Nm}=0.17), E$. puteanus $(\mathrm{Nm}=$ $0.27)$, or Hadenoecus opilionoides ( $\mathrm{Nm}=0.12$; Caccone and Sbordoni, 1987). In 24 populations of the amphipod Gammarus minus in West Virginia, $\mathrm{Nm}$ was found to be 0.264 and for three Virginia populations $N m=0.856$ covering a metric distance of c. $50 \mathrm{~km}$. However spring and cave habitats differed having respectively $N m=2.25$ and $N m=$ 0.214 suggesting that cave populations are isolated from their resurgence populations and that cave populations in different drainages are unconnected (Kane and Culver, 1992).

By contrast, much higher levels of gene flow are commonly encountered for non-cave dwellers. The restricted gene flow between the cave populations covering a small geographical area can be compared with genetic distance estimates from other studies. For example, the genetic distances (Rogers' Distance) between island populations of the coconut crab, Birgus latro, is 0.13 between islands in the Pacific Ocean and 0.19 between Pacific and Indian Ocean Islands (Lavery, 1991). By contrast, the same index for the cave millipedes in Cape Range vary between 0.19 and 0.36 within genetic provinces, 0.21 to 0.23 between adjacent provinces, and 0.58 between all provinces. Similarly, the mean fixation index $\left(\mathrm{F}_{\mathrm{ST}}\right)$ for all polymorphic loci between Drosophila spp. from

Table 12 Genetic profiles of individual millipedes from breeding populations in the laboratory. The five interprovince crosses were heterozygous for the appropriate alleles at all six diagnostic loci; i.e. they were definite $F_{1}$ hybrids. Caves C-167 and C-254 are geographically separated by $13 \mathrm{~km}$ and genetically separated by Nei's D $=0.62$.

\begin{tabular}{|c|c|c|c|c|c|c|c|c|}
\hline Cave & Group & Age & Acon & $A d a$ & $F d p$ & $M d h 2$ & PepB & PepD \\
\hline 167 & $\mathrm{~S}$ & juv & c & de & $c$ & e & $b$ & $d$ \\
\hline 167 & $S$ & juv & $c$ & $\mathrm{e}$ & $c$ & $\mathrm{e}$ & $b$ & $\mathrm{~d}$ \\
\hline 167 & $S$ & juv & c & de & $c$ & $\mathrm{e}$ & $b$ & $\mathrm{~d}$ \\
\hline 167 & $S$ & $\mathrm{ad}$ & $c$ & $\mathrm{~cd}$ & $c$ & $\mathrm{e}$ & $b$ & $\mathrm{~d}$ \\
\hline 167 & $S$ & ad & $c$ & $\mathrm{~cd}$ & C & $\mathrm{e}$ & $\mathrm{b}$ & $\mathrm{d}$ \\
\hline 167 & $S$ & $\mathrm{ad}$ & $\mathrm{c}$ & $\mathrm{d}$ & c & $e$ & b & $\mathrm{d}$ \\
\hline $167 \times 254$ & SxN & juv & $\mathrm{cd}$ & $\mathrm{df}$ & bc & ef & bd & $\mathrm{ad}$ \\
\hline $167 \times 254$ & SxN & juv & $\mathrm{cd}$ & $\mathrm{df}$ & bc & ef & $\mathrm{bd}$ & $\mathrm{ad}$ \\
\hline $167 \times 254$ & $S \times N$ & juv & $\mathrm{cd}$ & $\mathrm{df}$ & $b c$ & ef & bd & $\mathrm{ad}$ \\
\hline $167 \times 254$ & $S x N$ & juv & $\mathrm{cd}$ & $\mathrm{df}$ & $\mathrm{bc}$ & ef & $\mathrm{bd}$ & ad \\
\hline $167 \times 254$ & SxN & juv & $\mathrm{cd}$ & $\mathrm{cf}$ & $\mathrm{bc}$ & ef & $\mathrm{bd}$ & $\mathrm{ad}$ \\
\hline 254 & $\mathrm{~N}$ & $\mathrm{ad}$ & $d$ & f & b & $\mathrm{f}$ & $\mathrm{d}$ & $\mathrm{a}$ \\
\hline 254 & $\mathrm{~N}$ & $\mathrm{ad}$ & $\mathrm{d}$ & f & b & f & $\mathrm{d}$ & $\mathrm{a}$ \\
\hline 254 & $\mathrm{~N}$ & juv & $\mathrm{d}$ & f & $a b$ & f & $\mathrm{d}$ & a \\
\hline
\end{tabular}


different continents ranges from $\mathrm{F}_{\mathrm{ST}} 0.063(\mathrm{Nm}=$ 3.72) to $\mathrm{F}_{\mathrm{ST}} 0.169$ ( $\mathrm{Nm}=1.23$; Singh and Rhomberg, 1987). By contrast $F_{S T}$ for the cave millipede populations in Cape Range is $0.21(\mathrm{Nm}=0.94), 0.29$ $(\mathrm{Nm}=0.612)$ and $0.64(\mathrm{Nm}=0.141)$ for southern, northern and central areas respectively, an area in which the average separation distance between cave populations is only $4.1 \mathrm{~km}$.

\section{Taxonomic considerations}

Taxonomic assignments based on the small numbers of morphological characters available in the millipedes often prove inadequate or even provide incorrect partitions of phylogenetic diversity (Avise, 1989). Cryptic sibling species (Laing et al., 1976) may be common in cave populations, particularly where different species may have undergone convergent morphological evolution as part of adaptation to a troglobitic lifestyle. As with the amphipods from Cape Range (Humphreys and Adams, 1991; Adams and Humphreys, 1993), there is evidence that sibling species may be involved in some cave populations comprising the morphospecies Stygiochiropus communis. Each of the three genetic provinces contains a group of populations that are genetically isolated from the other two. Ignoring allele frequency differences, there are at least $17 \%$ fixed genetic differences between the three sub-regions (based on 18 loci). Such multiple fixed differences indicate that there is no genetic exchange between any of the sub-regions. Indeed, the genetic differences observed between sub-regional populations are at the higher end of the range normally observed for allopatric populations of a single species (Thorp, 1982, 1983).

Data from Dolichopoda cave crickets, Speonomus (Bathysciinae) beetles and Troglocaris cave shrimps indicate that populations differing by Nei's $D$ greater than 0.20 - the mean Nei's $D$ for $S$. communis between provinces - are reproductively isolated by post-mating barriers (Caccone and Sbordoni, 1987: 1211). Nonetheless, we have been able to generate $F_{1}$ hybrids of $S$. communis between populations representing the northern and southern provinces. The genetic identify of these hybrids was confirmed by allozyme typing at six diagnostic loci (Table 12). These two populations differ by $D=$ 0.615 , within the limits of divergence found between other arthropods species able to form interspecific hybrids.

Coyne and Orr (1989) modelled that total sexual isolation (i.e. to obtain species status) occurs at $D=$ 0.66 for allopatric species and $D=0.31$ for sympatric species of Drosophila. It is not yet known whether the Stygiochiropus hybrids are fully fertile as they would need to be for these two provinces to be conspecific. Clearly, the only way to fully address the issue of species boundaries in $S$. communis is to conduct rearing and fertility studies on $F_{1}$ crosses between each of the three provinces. Until this can be done, the provinces must be regarded as divergent parapatric populations of a single species.

\section{Connections between the caves}

Only quite recently has it been appreciated that caves act as accessible sampling points for an extensive community that typically inhabits the finer cavities (mesovoid subterranean spaces; milieu souterrain superficial, MSS: Juberthie and Delay, 1981) of the underground world and which may extend close to the surface (Juberthie et al., 1980; Oromi et al., 1991; Uéno, 1977). Furthermore, that the larger proportion of major caverns within a karst area do not open to the surface (Curl, 1966). If the Cape Range karst is a relatively undifferentiated sponge-work inhabited by troglobites then sampling from the scattered larger caves may be expected to show gene flow that is inversely related to the distance separating the caves. This isolation by-distance-model was rejected on account of the fixed differences between nearby cave populations.

In general, the hypogean environment for the most part remains inaccessible to direct study and the biology and dynamics of these systems must be interpreted from sampling the few points of access, either in caves, the MSS or down boreholes. Elsewhere, water tracing has shown that there are many fine leads, which cannot be entered by cavers but which are suitable for troglobites - and stygobites, their aquatic equivalent - which may link different caves even between different karst provinces (Ford and Williams, 1989). Furthermore, where there is no link resulting from karstification, then connection may be through the larger spaces in the rocks beneath the soil layer (Juberthie and Delay, 1981). Hence, there are situations where it is possible for the migration of troglobites to occur both between caves and between karst provinces across non-karstic regions. Nonetheless, the proportional make up of species in the MSS may not be the same as found in the caves (Juberthie et al., 1980) which implies that at best the MSS would act as a species filter between caves or karst provinces. The amount of migration permitted by a combination of these routes is a measure of the permeability of the system to troglobites; this general level of biological connection should be reflected in the rate of gene flow between populations in different caves.

Cape Range is one karst region and lacks the habitat associated with MSS (post-glacial scree slopes under deep soil). The lack of gene flow for both terrestrial and aquatic species (Humphreys, 1989; Humphreys and Adams, 1991) across the main geomorphological divides both within Cape Range sensu stricto, and between Cape Range and 
its coastal plain suggests that there is no MSS equivalent - or deep water connection - between the genetic provinces. In addition, the frequent occurrence of fixed differences in adjacent caves suggests that these potential migration routes are not general even within the karst provinces.

Troglobitic animals may move through the immediate subsurface spaces even in non-karstic areas (Uéno, 1977; Juberthie et al., 1980; Juberthie and Delay, 1981; Oromí et al., 1991). Hence, the presence of distinct genetic provinces, and the lack of gene flow in some places even within genetic provinces, provides strong support for the hypothesis that there is no equivalent of the MSS covering Cape Range. This is consistent with the the speciation of Stygiochiropus (Humphreys and Shear, 1993; Shear and Humphreys, 1996), and of the Schizomida (Harvey, 2001), in the northern part of Cape Range and on the coastal plain

\section{Implications for management}

Observations made in this study lead to a number of inferences with management implications. These are drawn together in Table 13 and some of them are further discussed in the following sections.

Taxonomic classification is a primary determinant of management priorities for endangered species (Daugherty et al., 1990). The Cape Range karst is partly included within Cape Range National Park which encompasses the centre of the western side of the range. Stygiochiropus sympatricus, $S$. isolatus and $S$. peculiaris lie entirely outside the National Park. However, all three species are currently listed as threatened species under the Wildlife Conservation Act, Western Australia, the first two in the vulnerable status, while the last, under the name Camerons Cave Millipede, with the status critically endangered. S. peculiaris forms part of a cave community which is also declared protected. While the $S$. communis populations overall are well represented in Cape Range National Park, the bulk of the southern province lies outside the National Park as do important elements of the northern province. Hence, the three genetic provinces of $S$. communis, as well as diverse other troglobitic species, argue that the Cape Range karst area be

Table 13 Inferences drawn from the data presented in this paper and their potential management implications.

\begin{tabular}{lll}
\hline Observation & Inference & Management implication \\
\hline Stygiochiropus in caves. & Troglobitic. & Needs subsurface connections to migrate. \\
S. communis in Cape Range proper. & No connection with coastal plain. & Delimits distribution \\
Fixed differences (FD) between S. & No underground connection & Treat separately and to maintain \\
communis in northern, central and & between these provinces; no MSS. & biodiversity don't mix populations.
\end{tabular}
southern parts of distribution.

Coincidence of genetic province limits and geomorphology.

Isolated species of Stygiochiropus in far north

Within provinces often FD between populations in adjacent surface catchments and no FD within catchments.

Several distinct species of Stygiochiropus in the far north.

S. communis populations in southern province genetically relatively invariant.

Usually low gene flow between adjacent caves even when no FD.

S. communis populations differ within and between genetic provinces.

S. communis populations broadly similar to other taxa, both aquatic and terrestrial
Exposure of marly Mandu

Limestone acts as a barrier to underground dispersal.

No subterranean connection with south.

Within Cape Range proper surface and underground water catchments are largely concordant.

Immature karst development with few connections between caves.

Mature karst development with extensive connections between caves.

Limited connections, if any, between adjacent caves

Numerous scale effects on populations, as typical of karst itself.

Data generally applicable to other troglobite populations
Removal of barrier will mix genetically distinct populations.

Several individual caves contain isolated species; probably numerous unique cave communities

Suggests simplified approach to risk management of cave communities.

Expect high between cave species diversity.

Expect high provincial species diversity.

Genetic diversity of $S$. communis within each cave a significant part of its value, in addition to other species in the cave.

Incorporate the different scales into conservation, impact assessment, management considerations and research.

Populations need to be protected throughout Cape Range 
considered at least three separate areas for purpose of management.

The large and consistent differences between provinces suggest that the populations in the genetic provinces may be of specific status. The null hypothesis of panmixia is also refutable within provinces on the evidence of the allozyme data. The levels of genetic divergence are quite high, and by themselves might indicate the presence of more than one species. However, the high levels of polymorphism, coupled with the fact that only a small component of the genetic distance estimates is due to the fixation of unique alleles, suggests that the concept of a single, highly variable species, consisting of discrete sub-populations is the more appropriate model within the genetic provinces.

The genetic structuring of the $S$. communis populations both within, and especially between genetic provinces, represents an important component of the biodiversity in the Cape Range subterranean fauna. Furthermore, the general consistency of the genetic structuring with that found in other taxa of the subterranean fauna, from both aquatic and terrestrial habitats (Humphreys and Adams, 1991; Adams and Humphreys, 1993) suggests that the described pattern may be general and fundamental to understanding the structuring of the Cape Range subterranean ecosystem.

To maintain the considerable genetic diversity described, the management of the karst area would need to maintain populations throughout Cape Range and to prevent the accidental or deliberate mixing of populations of $S$. communis - probably all troglobitic species - from different genetic stocks, particularly between the genetic provinces. Mixing could conceivably occur as part of any of the following three scenarios:

(1) accidental transport between caves. This is considered unlikely for S. communis or Nocticola flabella Roth (Nocticolidae), as they are very sensitive to desiccation, but is quite possible with more resilient trogolobites such as the schizomid Draculoides vinei and the nemobiine cricket Ngamarlanguia luisae Rentz and Su,

(2) deliberate mixing, as for an experimental introduction. Experimental transfers between karst regions have been conducted in Western Australia, albeit under constraint (E. Jasinska, personal communication, 1999) - or,

(3) the removal of barriers to dispersal between populations, especially between genetic provinces. The most likely way this may occur is by the development of an artificial MSS formed in association with limestone quarrying activities, landscaping, pipelines, paving or road development. For example, the road base would change the superficial subterranean environment which would permit the movement of troglobites beneath the roadway and may allow mixing of genetic stocks - cave populations in different genetic provinces are known to be as close as $1.2 \mathrm{~km}$. in places either across otherwise inhospitable Tulki Limestone or over non-cavernous Mandu Limestone in the gorges.

The presence of three Stygiochiropus species at single localities in the northern $30 \%$ of Cape Range is consistent with a lack of gene flow in this northern area and is in accord with the model for karst development which argues that the northern region should have less well integrated karst, hence fewer conduits for genetic interchange.

While it is not often worthwhile to conduct genetic assessment of individual species for conservation purposes, the use of molecular genetics techniques can be highly informative, and are frequently applied to the conservation biology of oceanic island faunas (Medeiros et al., 2000)

The data on S. communis from Cape Range show the presence of isolated genetic provinces with marked, and geographically concordant, genetic differences. As the genetic provinces have, in part, distinctive geomorphological boundaries this assignment may serve as an exemplar for the entire troglobitic community and thus aid regional management; notwithstanding that levels of gene flow are often considered to be dependent on the characteristics of the species rather than the availability of routes for dispersal (Caccone, 1985). In a similar manner, but on a far larger scale, molecular data have elsewhere been found useful to define regional freshwater fish provinces (Bermingham and Avise, 1986).

\section{A model for Cape Range}

As a working model for Cape Range consider a cave where on occasion large populations of caveinhabiting animals concentrate in areas recently reactivated by the influx of water and its contained organic matter, as has been both observed in nature and demonstrated experimentally (Humphreys, 1991d). These populations communicate via the finer leads with populations in other overt caves within the neighbourhood or sub-region, the finer leads acting as choke points to gene flow between the populations in neighbouring caves.

Population increase and breeding become more frequent following sporadic inputs of water and food which are dependent on the characteristics of the catchment. This pulse is followed by a period during which resources decline at a rate dependent on the drying characteristics of the cave and the population size or both (Humphreys, 1991d). At some threshold level the millipedes cease breeding and the population assumes a typical old-aged structure (Humphreys, 1990, 1991d; Humphreys and Shear, 1993). Local extinction of the population will follow if the cave remains long unflooded. 
The periodicity of these events differs between caves in both the frequency of flooding ('renewal') and the time course of the decline in the suitability of the cave to support troglobite populations. These events occur in different caves at different frequencies, so there are foci of asynchronous pulses of rising or declining populations scattered in a mosaic throughout the range. In consequence a particular lead from an 'active' cave may or may not connect to a thriving or even an extant population in an adjacent cave.

As mentioned above, many and perhaps most of the troglobite populations are not associated with caves per se, but may inhabit mesovoids more extensively penetrating the limestone. Extensive parts of both the southern and northern parts of Cape Range are covered by fixed desert sand dunes of Pleistocene age (Wyrwoll et al., 1993). In the northern area, where the dunes cover parts of the range and the coastal plain, sampling from bores has shown that the area supports both terrestrial (Schizomida) and aquatic troglobites (Atyidae). In the southern area, sampling down bores has shown the area supports aquatic troglobites (Atyidae, Amphipoda). Furthermore, a cave south of the dune field contains a population of S. communis (C-203: Figure $5 \mathrm{a}$ ) that is genetically close to the population in C-15 which lies $26 \mathrm{~km}$ away, to the north of the southern dune field. This implies a continuous population of $S$. communis of the southern province type inhabiting the extensive karst deeply buried for prolonged periods below these fixed dunes. Owing to the buffering and filtering effects of the deep sand cover these populations probably inhabit a remarkably stable and low energy environment compared with the cave populations examined in this study.

The patchiness of this karst system may itself be important to the long-term persistence of the troglobite community. Whereas the received wisdom has been that environmental variation can be averaged out without losing the essential dynamics of the populations, it is now known that such heterogeneities, causing frequent extinctions and recolonisation of local populations, often play a significant role in gene flow (Slatkin, 1987) and in structuring large populations, especially lessening the risk of extinction (Shorrocks and Swingland, 1990).

\section{ACKNOWLEDGEMENTS}

We would like to thank the following people for supporting this work in many and varied ways: Darren Brooks, Malcolm East, Mark Harvey, Angus Humphreys, Barbara Jones, Malcolm Krieg, Caroline Lawrence, Bill Shear, Brian Vine, Julianne Waldock, Ray Wood, Brigitte Winton and Rae Young. Bob Mesibov's detailed and perceptive comments on a draft of this paper greatly improved its structure. The work was conducted by permission of the Department of Conservation and Land Management and the Lessees of Exmouth Gulf Station. This work was funded variously by the Australian National Parks and Wildlife Service Consultancy Programme, The Heritage Council under the National Estate Programme, the Western Australian and South Australian Museums, and by many volunteers.

\section{REFERENCES}

Adams, M., Baverstock, P.R., Watts, C.H.S. and Reardon, T. (1987). Electrophoretic resolution of species boundaries in Australian Microchiroptera: I. Eptesicus (Chiroptera: Vespertilionidae). Australian Journal of Biological Science 40: 143-162.

Adams, M. and Humphreys, W.F. (1993). Patterns of genetic diversity within selected subterranean fauna of the Cape Range peninsula, Western Australia: systematic and biogeographic implications. Records of the Western Australian Museum, Supplement No. 45: 145-164.

Alexander, E.C. and Quinlan, J.F. (1992). Practical Tracing of Groundwater, with Emphasis on Karst Terranes. Short course manual presented at the Annual Meeting of the Geological Society of America, 24 Oct. 1992, 38 pp.

Avise, J.C. (1989). A role for molecular genetics in the recognition and conservation of endangered species. Trends in Ecology and Evolution 4: 279-281.

Barton, N.H. and Slatkin, M. (1986). A quasi-equilibrium theory of the distribution of rare alleles in a subdivided population. Heredity 56: 409-415.

Bermingham, E. and Avise, J.C. (1986). Molecular zoogeography of freshwater fishes in the southeastern United States. Genetics 113: 939-965.

Caccone, A. (1985). Gene flow in cave arthropods: a quantitative and qualitative approach. Evolution 39: 1223-1235.

Caccone, A. and Sbordoni, V. (1987). Molecular evolutionary divergence among North American cave crickets. I. Allozyme variation. Evolution 41: 11981214.

Carson, H.L. (1990). Increased genetic variation after a population bottleneck. Trends in Ecology and Evolution 5: 225.

Condon, M.A., Johnstone, D., Perry, W.J. and Crespin, I. (1955). The Cape Range structure, Western Australia. Australian Bureau of Mineral Resources, Bulletin 21: 1-82.

Coyne, J.A. and Orr, H.A. (1989). Patterns of speciation in Drosophila. Evolution 43: 363-381.

Curl, R. (1966). Caves as a measure of karst. Journal of Geology 74: 798-830.

Daugherty, C.H., Cree, A., Hay, J.M. and Thompson, M.B. (1990). Neglected taxonomy and continuing extinctions of Tuatara (Sphenodon). Nature 347: 177179.

Ellstrand, N.C. and Elam, D.R. (1993). Populations genetics of small population size: implications for 
plant conservation. Annual Review of Ecology and Systematics 24: 217-242.

Ford, D.C. and Williams, P.W. (1989). Karst Geomorphology and Hydrology. Unwin Hyman, London.

Hamilton-Smith, E., Kiernan, K. and Spate, A. (1998). Karst management considerations for the Cape Range karst province, Western Australia. Western Australian Department of Environmental Protection, Perth.

Harvey, M.S. (2001). New cave-dwelling schizomids (Schizomida: Hubbardiidae) from Australia. Records of the Western Australian Museum, Supplement No. 64: 171-185.

Harvey, M.S., Gray, M.R., Hunt, G.S. and Lee, D.C. (1993). The cavernicolous Arachnida and Myriapoda of Cape Range, Western Australia. Records of the Western Australian Museum, Supplement No. 45: 129 144.

Hochberg, Y. (1988). A sharper Bonferroni procedure for multiple tests of significance. Biometrika 75: 800-802.

Howarth, F.G. (1983). Ecology of cave arthropods. Annual Review of Entomology 28: 365-389.

Hudson, P. and Adams, M. (1996). Allozyme characterisation of the salt-lake spiders ( $L y$ cosa: Lycosidae: Araneae) of southern Australia: systematic and population genetic implications. Australian Journal of Zoology 44: 535-567.

Humphreys, W.F. (1989). The status of relict cave fauna of Cape Range, Western Australia, especially the Schizomida. Unpublished Report to the Australian National Parks and Wildlife Service, Canberra. 104 pp.

Humphreys, W.F. (1990). The biology of a troglobitic schizomid (Chelicerata: Arachnida) from caves in the semi-arid Cape Range, Western Australia. Acta zoologica Fennica 190: 181-186.

Humphreys, W.F. (1991a). Survey of caves in Cape Range, North West Cape peninsula, Western Australia. Unpublished Report to the Australian Heritage Commission and the Western Australian Heritage Committee. $178 \mathrm{pp}$.

Humphreys, W.F. (1991b). The cave fauna of Cape Range: specific analyses. Unpublished Report to the Australian National Parks and Wildlife Service, Canberra. $132 \mathrm{pp}$.

Humphreys, W.F. (1991c). Biological research into the Cape Range karst area, North West Cape peninsula, Western Australia. In Brooks, S. (Ed.). Cave Leeuwin Proceedings of the 18th Biennial Conference of the Australian Speleological Federation Inc., Margaret River, Western Australia. 30 December 1990-5 January 1991: 614. Australian Speleological Federation Inc., Nedlands, Western Australia. 113 pp.

Humphreys, W.F. (1991d). Experimental reactivation of pulse driven populations in a terrestrial troglobite community. Journal of Animal Ecology 60: 609-623.

Humphreys, W.F. (ed.). (1993a). The biogeography of Cape Range, Western Australia. Records of the Western Australian Museum, Supplement No. 45: 1-248.

Humphreys, W.F. (1993b). The significance of the subterranean fauna in biogeographical reconstruction: examples from Cape Range peninsula,
Western Australia. Records of the Western Australian Museum, Supplement No. 45: 165-192.

Humphreys, W.F. (1993c). Cave fauna in semi-arid tropical Western Australia: a diverse relict wet-forest litter fauna. Mémoires de Biospéologie 20: 105-110.

Humphreys, W.F. (2000). The hypogean fauna of the Cape Range peninsula and Barrow Island, north-west Australia. In H.Wilkens, D.C. Culver and W.F. Humphreys (eds), Ecosystems of the World, vol. 30. Subterranean Ecosystems: Elsevier, Amsterdam: 581601.

Humphreys, W. F. and Adams, M. (1991). The subterranean aquatic fauna of the North West Cape peninsula, Western Australia. Records of the Western Australian Museum 15: 383-411.

Humphreys, W.F., Adams, M. and Vine, B. (1989). The biology of Schizomus vinei (Chelicerata: Schizomida) in the caves of Cape Range, Western Australia. Journal of Zoology, London 217: 177-201.

Humphreys, W.F. and Collis, G. (1990). Water loss and respiration of cave arthropods from Cape Range, Western Australia. Comparative Biochemistry and Physiology 95A: 101-107.

Humphreys, W.F. and Shear, W.A. (1993). Troglobitic millipedes (Diplopoda: Paradoxosomatidae) from semi-arid Cape Range, Western Australia systematics and biology. Invertebrate Taxonomy 7: 173195.

Juberthie, C. and Delay, B. (1981). Ecological and biological implications of the existence of a Superficial Underground Compartment. Proceedings of the 8th International Congress of Speleology, Bowling Green, Kentucky 6: 203-206.

Juberthie, C., Delay, B. and Bouillon, M. (1980). Extension du milieu souterrain en zone non calcaire: description d'un nouveau milieu et de son peuplement par les Coléoptères troglobies. Mémoires de Biospéologie 7: 19-52.

Kane, T.C. and Culver, D.C. (1992). Biological processes in space and time: analysis of adaptation. In A.I. Camacho (ed), The natural history of biospeleology: Monografias Museo Nacional de Ciencias Naturales, Madrid: 377-399.

Laing, C.D., Carmody, G.R. and Peck, S.B. (1976). How common are sibling species of cave-inhabiting invertebrates? American Naturalist 110: 184-198.

Lavery, S. (1991). Genetic population subdivision in the coconut crab, Birgus latro (Anomura: Coenobitidae). Memoirs of the Queensland Museum 31: 210.

McCauley, D.E. (1991). Genetic consequences of local population extinction and recolonisation. Trends in Ecology and Evolution 6: 5-8.

Matthews, P.G. (1985). Australian Karst Index 1985. Australian Speleological Federation Inc., Broadway, New South Wales.

Medeiros, R., Brito, C., Martins, A.M.F., Jordaens, K., Van Riel, P., De Wolf, H., Breugelmans, K. and Backeljau, T. (2000). Conservation genetics of the endemic Azorean slug Plutonia atlantica (Mollusca, Pulmonata). Biological Conservation 93: 77-84.

Nei, M. (1978). Estimation of average heterozygosity and genetic distance from a small number of individuals. Genetics 89: $583-590$ 
Neigel, J.E. (1997). A comparison of alternative strategies for estimating gene flow from genetic markers. Annual Review of Ecology and Systematics 28: 105-128.

Olivieri, I., Couvet, D. and Gouyon, P. (1990). The genetics of transient populations: research at the metapopulation level. Trends in Ecology and Evolution 5: 207-210.

Oromi, P., Martin, J.L., Medina, A.L. and Izquierdo, I. (1991). The evolution of the hypogean fauna of the Canary Islands. In E.C. Dudley (ed.), The Unity of Evolutionary Biology, vol. 1: 380-395. Dioscorides Press, Portland, Oregon:.

Raymond, M., and Rousset, F. (1995). GENEPOP (version 1.2): population genetics software for exact tests and ecumenicism. Journal of Heredity 86: 248-249.

Richardson, B.J., Baverstock, P.R. and Adams, M. (1986). Allozyme Electrophoresis: a Handbook for Animal Systematics and Population Studies. Academic Press, Sydney.

Rogers, J.S. (1972). Measures of genetic similarity and genetic distance. Studies in genetics VII University of Texas Publication 7213: 145-153.

Sarre, S., Schwaner, T.D. and Georges, A. (1990). Genetic variation among insular populations of the sleepy lizard, Trachydosaurus rugosus Gray (Squamata: Scincidae). Australian Journal of Zoology 38: 603-616.

Shear, W.A. and Humphreys, W.F. (1996). A new Stygiochiropus from a North West Cape (Western Australia) coastal plain cave (Diplopoda, Polydesmida, Paradoxosomatidae). Records of the Western Australian Museum 17: 447-449.

Shorrocks, B. and Swingland, I.R. (eds) (1990). Living in a Patchy Environment. Oxford University Press, Oxford.

Singh, R.S. and Rhomberg, L.R. (1987). A comprehensive study of genetic variation in natural populations of Drosophila melanogaster. I Estimates of gene flow from rare alleles. Genetics 115: 313-322.

Slatkin, M. (1981). Estimating level of gene flow in natural populations. Genetics 99: 323-335.
Slatkin, M. (1985). Rare alleles as indicators of gene flow. Evolution 39: 53-65.

Slatkin, M. (1987). Gene flow and the geographic structure of natural populations. Science 236: 787-792.

Slatkin, M. and Barton, N. H. (1989). A comparison of three indirect methods for estimating average levels of gene flow. Evolution 43: 1349-1368.

StatSoft Inc. (1997). STATISTICA for Windows [Computer program manual]. Tulsa, Oklahoma.

Thorp, J.P. (1982). The molecular clock hypothesis: biochemical evolution, genetic differentiation and systematics. Annual Review of Ecology and Systematics 13: $139-168$.

Thorp, J.P. (1983). Enzyme variation, genetic distance and evolutionary divergence in relation to levels of taxonomic separation. In G.S. Oxford, and D. Rollinson (eds), Protein Polymorphism: Adaptive and Taxonomic Significance. Systematics Association Special volume No. 24. Academic Press, London: 131152.

Trexler, J.C. (1988). Hierarchical organization of genetic variation in the Sailfish Molly, Poecilia latipinna (Pisces: Poeciliidae). Evolution 42: 1006-1017.

Uéno, S.I. (1977). The biospeleological importance of noncalcareous caves. Proceedings of the 7th International Speleological Congress, Sheffield: 407-408.

Wright, S. (1931). Evolution in Mendelian populations. Genetics 16: 97-159.

Wyrwoll, K-H., Kendrick, G.W. and Long, J.A. (1993). The geomorphology and Late Cenozoic geological evolution of the Cape Range - Exmouth Gulf region. Records of the Western Australian Museum, Supplement No. 45: 1-23.

Manuscript received 24 February 2000; accepted 5 July 2000.

Edited by M.S. Harvey 